\title{
Contrasting carbonate depositional systems for Pliocene cool-water limestones cropping out in central Hawke's Bay, New Zealand
}

\author{
VINCENT CARON \\ CAMPBELL S. NELSON \\ PETER J. J. KAMP \\ Department of Earth Sciences \\ University of Waikato \\ Private Bag 3105 \\ Hamilton, New Zealand \\ email: c.nelson@waikato.ac.nz
}

\begin{abstract}
Pliocene limestone formations in central Hawke's Bay (eastern North Island, New Zealand) accumulated on and near the margins of a narrow forearc basin seaway within the convergent Australia/Pacific plate boundary zone. The active tectonic setting and varied paleogeographic features of the limestone units investigated, in association with probable glacioeustatic sea-level fluctuations, resulted in complex stratigraphic architectures and contrasting types of carbonate accumulation on either side of the seaway. Here, we recognise recurring patterns of sedimentary facies, and sequences and systems tracts bounded by key physical surfaces within the limestone sheets. The facies types range from Bioclastic (B) to Siliciclastic (S) end-members via Mixed (M) carbonatesiliciclastic deposits. Skeletal components are typical coolwater associations dominated by epifaunal calcitic bivalves, bryozoans, and especially barnacles. Siliciclastic contents vary from one formation to another, and highlight siliciclastic-rich limestone units in the western ranges versus siliciclastic-poor limestone units in the eastern coastal hills. Heterogeneities in facies types, stratal patterns, and also in diagenetic pathways between eastern and western limestone units are considered to originate in the coeval occurrence in different parts of the forearc basin of two main morphodynamic carbonate systems over time.
\end{abstract}

The depositional system of the eastern (highest accretionary ridge) sector carbonates is balanid-dominated, detached from a landmass, and associated carbonate factories developed upon and about actively growing thrustcored antiforms. By contrast, the depositional setting for the western siliciclastic-rich limestone occurrences was a continent-attached platform. Here, moderate to high contents of Mesozoic basement-derived siliciclastics indicate that carbonates probably formed and accumulated on a narrow shelf regularly provided with terrigenous sediments, and influenced by strong storm and tidal currents, which locally promoted balanid growth. A similar morphological system is envisaged for the youngest cyclothemic formations deposited in the central part of the forearc basin.
Keywords cool-water limestones; carbonate platforms; attached platforms; detached platforms; depositional facies; stratigraphic architecture; Pliocene; Hawke's Bay

\section{INTRODUCTION}

The classification of carbonate platforms traditionally builds upon morphotectonic characteristics of the depositional setting, including the profile of the inherited surface upon which sediments may form and accumulate, and attachment or detachment to a landmass. Accordingly, most modern syntheses advocate the distinction between (1) ramps, either homoclinal or distally steepened, (2) epeiric platforms, and (3) flat-topped shelves, either rimmed or unrimmed, and isolated or not (Wright \& Burchette 1996; Pomar 2001). The recognition of such morphological systems that host carbonate deposits, and evolve in response to relative sea-level changes, has become determinant to hydrocarbon exploration, including high-resolution analysis of seismic profiles, and modelling of sedimentary architectures in conceptualised sequence stratigraphic frameworks. However, accurate interpretation of physical stratal geometries and predictability of stratigraphic reservoirs from conceptual models not only depends upon the integration and comprehension of morphotectonic factors, but also of factors that drive rapid vertical and lateral facies changes, and heterogeneities in porosity alteration processes, as observed in many ancient carbonate systems. Hydrodynamic regimes, the availability and renewal of trophic resources, character of substrate, climate and latitude, and rates and dispersal mechanisms of siliciclastic fluxes are all genetic factors that directly impact the productivity of carbonate factories and especially influence the composition of carbonate biota and diagenetic pathways. Such factors are particularly critical to carbonate production in cool-water environments, where heterotrophic and photo-independent biota, typically suspension feeders (e.g., bryozoans) and filter feeders (e.g., barnacles), are extremely sensitive to the amount of sediments and nutrients in suspension in the water column (Henrich \& Freiwald 1995).

Most previous studies of modern and ancient cool-water carbonates have documented accumulation on sloping shelves (Boreen \& James 1995; Betzler et al. 1997; Pedley \& Grasso 2002; Brachert et al. 2003) or epeiric ramps (Lukasik et al. 2000) attached to a landmass, while much less is known about the dynamics of continent-detached cool-water carbonate systems. This paper reports the sedimentologic and stratigraphic attributes of the predominantly Plioceneage limestones of eastern North Island, New Zealand (Fig. 1), informally known as the Te Aute limestones (Nelson et al. 2003), whose cool-water character has already been demonstrated by Kamp et al. (1988). Detailed lithofacies, stratal, and diagenetic analyses of these limestones indicate that two distinct morphological carbonate systems, namely continent-attached and continent-detached, co-evolved within 


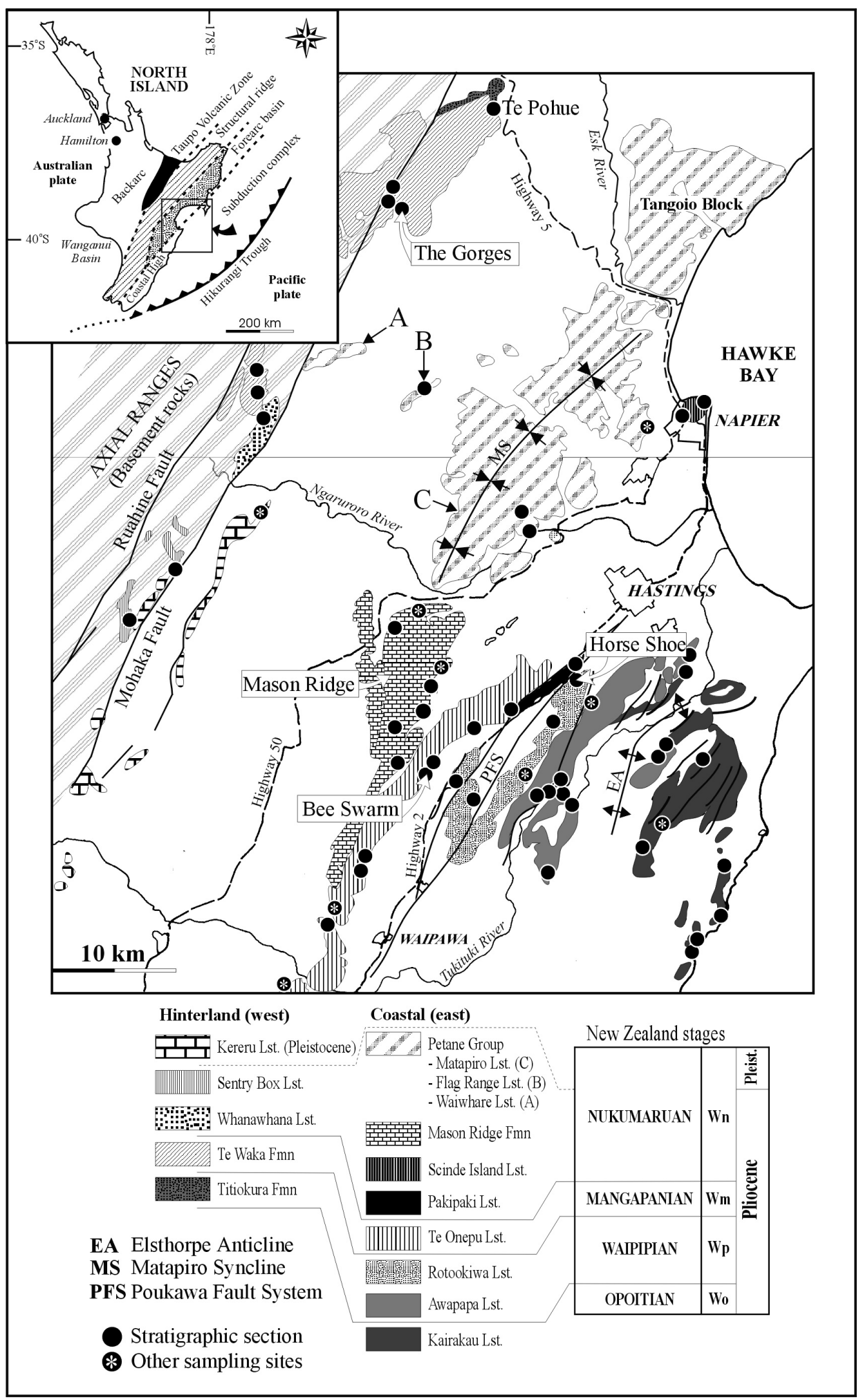

Fig. 1 General distribution of the Pliocene limestone units in the central Hawke's Bay region (modified from Beu 1995), and location of logged sections and other sampling sites (see Caron 2002). Inset: The plate tectonic setting of North Island.

a former forearc basin seaway. These provide the unique opportunity to assess the influence of morphodynamic and genetic factors (Pomar 2001) on the development of coolwater carbonate systems.

\section{GEOLOGICAL AND TECTONIC SETTING}

Eastern North Island Pliocene-Pleistocene sedimentary rocks represent the upper portion of a $5 \mathrm{~km}$ thick Neogene forearc basin-fill sequence. The forearc basin is one of six tectonogeomorphic elements in eastern North Island (Fig. 1, inset) that formed in response to the evolution of the convergent Australia/Pacific plate boundary zone since the close of the Oligocene (Ballance 1993). The subduction system is bounded to the east by the Hikurangi Trough where the oceanic crust of the Pacific plate is obliquely subducted beneath the continental lithosphere of North Island. A subduction accretionary complex consisting of thrust fault-controlled 


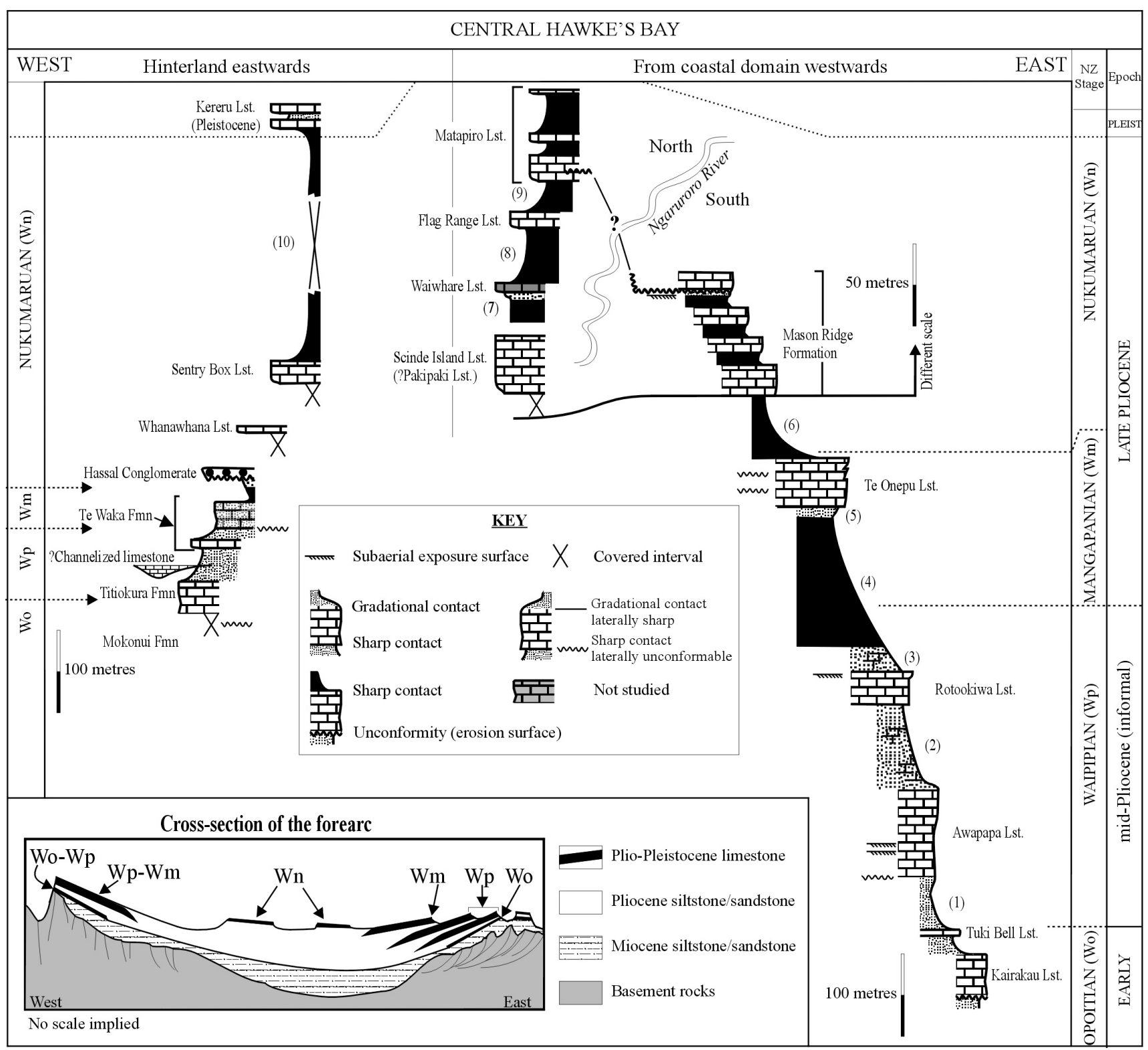

Fig. 2 Regional stratigraphic relationships between the various Pliocene limestone units towards the eastern (right) and western (left) sides of the forearc basin in central Hawke's Bay. Interbedded units, typically siliciclastic dominated, are (Beu 1995): (1) Mokopeka Sandstone; (2) Pukekura Calcarenite; (3) Waikareao Calcarenite; (4) Raukawa Mudstone; (5) Argyll Sandstone; (6) Makaretu Mudstone; (7) Willowford Mudstone; (8) Crownthorpe Mudstone; (9) Waitio Mudstone; (10) Ohara Mudstone. Inset: Schematic cross-section through the basin and inferred lateral relationships between the Pliocene strata and their ages (modified from Kamp et al. 1988).

anticlinal ridges and slope-parallel basins (Lewis \& Pettinga 1993) lies northwest and inboard of the Hikurangi Trough. The forearc basin represents the major topographic and structural depression associated with the accretionary complex, and is bounded to the west by a structural ridge of Mesozoic basement (Torlesse Terrane) rocks (axial ranges) separating the accretionary complex from the Taupo Volcanic Zone and the backarc region (Fig. 1, inset). In early Pliocene time, the structural ridge formed a central North Island highland surrounded by shelf-like shoal areas (Beu 1995).

Although a minor component of the basin-infill Neogene stratigraphy, temperate limestone units can locally be thick and quite extensive. These Te Aute limestones constitute a greater proportion of the stratigraphic record along the western and eastern margins of the forearc basin, grading basinward into siltstone and sandstone successions (Fig. 2, inset). Kamp et al. (1988) and Kamp \& Nelson (1987, 1988) suggested that the formation and evolution of these carbonate successions were closely related to the tectonic evolution of the forearc basin. As a result of subduction processes, differential uplift of the eastern margin (coastal high) of the forearc basin induced progressive narrowing and shallowing, which by mid-Pliocene times had constricted the basin into a northeast-southwest-trending seaway, the Ruataniwha Strait of Beu (1995), situated near $40^{\circ} \mathrm{S}$ paleolatitude.

The outcrop pattern of the early and mid-Pliocene occurrences, especially the more eastern ones adjacent to the inboard margin of the subduction complex, demonstrates that deposition migrated towards the centre of the basin over time, the younger sheets being present close to the forearc basin 
axis and at lower elevations compared with older Pliocene sheets located on the outer margins of the basin (Fig. 1). By late Pliocene time, the coastal high had become emergent and, as differential uplift persisted after the Pliocene, the early Pleistocene limestone units formed towards the axis of the basin (Kamp et al. 1988; Beu 1995).

\section{SEDIMENTOLOGY OF THE PLIOCENE LIMESTONES}

The Te Aute limestone units of central Hawke's Bay are generally moderately well to poorly exposed in cliffs along the eastern flanks of north-south-oriented parallel ranges, in quarries, and in road cuttings. In a down-dip direction, from east to west, the basinward transition of the limestone units into sandstone and siltstone is mainly inferred from the lithologies intersected in exploration wells in central parts of the basin (Harmsen 1990). As a result, stratal geometries in this direction are poorly documented. To the west, a current mapping project (K. Bland pers. comm.) is assessing the stratigraphic geometry of the Pliocene successions both along strike and in a down-dip direction, from west to east, as river valleys permit such investigation. Rocks are brownish to light coloured, grainy, locally profusely fossiliferous, and show various degrees of case-hardening, typically blurring fine sedimentary structures. The strata are 5-120 m thick, pointing at sheet-like to pinch-out geometries. The limestones are typically relatively unconsolidated, but can be well cemented in places (Caron 2002).

\section{Methods}

The sedimentologic study builds upon the detailed description and sampling of 47 stratigraphic sections (Caron 2002) through the many limestone formations in central Hawke's Bay (Fig. 1, 2). Macrofossils of the family Pectinidae have been identified as practical field means of determining the ages of the strata (Beu 1995). Over 600 polished thin-sections were prepared and examined in this study, using the scheme of Dunham (1962) for limestone classification. The point-counting method developed by Chayes (1956) was applied to calculate the percentages of various grain types, including barnacles, bryozoans, bivalves, quartz, and other siliciclasts. Benthic and planktic foraminifers, brachiopods, echinoderms, gastropods, red algae, and unidentified clasts, being typically minor components (total $<15 \%$ in most cases), were grouped in a single class ("potpourri") so as not to distort the results. The number of points needed to attain a certain reliability was controlled with the aid of charts (Galehouse 1971) for a confidence interval of $95 \%$. Thus, for each analysis, a minimum of two 200-point counts was performed on separate portions of 420 thin-sections to reduce errors linked to rock heterogeneity. Standard deviation varied between 1 and $5 \%$, depending on particle frequency. Data collected were used to determine skeletal assemblages following the classification scheme of Hayton et al. (1995). A further step in the microfacies analysis was the clustering of point-count data from 351 thin-sections (squared euclidean distances, complete linkage). This differed from the Hayton et al. (1995) analyses in that siliciclastic components were also taken into account. Full data are recorded in Caron (2002).

\section{Sedimentary facies}

Fourteen depositional facies have been erected for the Pliocene bioclastic and siliciclastic rocks in central Hawke's
Bay. Three major facies assemblages have been established: Bioclastic (B), Mixed carbonate-siliciclastic (M), and Siliciclastic (S), as follows: (1) Bioclastic facies (B1-3) that include fossiliferous rudstone (B1a-c), medium to coarse grained bioclastic-rich grainstone (B2a-b), and fine to medium grained packstone (B3a-b); (2) Mixed carbonatesiliciclastic facies (M1-3), transitional between bioclastic and siliciclastic facies, include interbedded grainstone and packstone (M1), grainstone and terrigenous packstone (M2), and terrigenous packstone and calcareous sandstone (M3); and (3) Siliciclastic facies (S1-3) include skeletal sandstone (S1), silty sandstone (S2), and mudstone (S3). Lithofacies correspond to a wide spectrum of depositional environments ranging from below storm-wave base, in outer shelf-type settings, to predominantly shallow-water shoreface-type conditions under the influence of strong bottom currents, both tide and storm driven.

Table 1 summarises diagnostic characteristics of the different sedimentary facies, including their constituents, physical structures, and ichnology. It also notes an interpreted depositional setting for each facies, elaborated upon in Caron (2002). Illustrations of some key facies features are presented in Fig. 3 and 4.

\section{Skeletal and microfacies assemblages}

Using the Hayton et al. (1995) classification scheme, the Pliocene limestone units in central Hawke's Bay fall into three major compositional skeletal associations: (1) barnamol, dominated by barnacles and bivalve molluscs; (2) bimol, or bivalve-dominated carbonate sediments (infaunal and/or epifaunal molluscs); and (3) bryomol, or bryozoan-dominated carbonate sediments with various amounts of bivalve molluscs. Hayton et al. (1995) devised their classification scheme to easily determine the skeletal assemblage of any coarse-grained temperate skeletal carbonate sample independently of its terrigenous content. Consequently, samples classified as barnamol, for example, can have highly variable siliciclastic contents related either to changes in external sediment input, or to transport and redeposition of skeletal clasts in terrigenous-dominated settings. Further, with decreasing grain sizes, misidentification of bioclasts can make the determination of skeletal assemblages difficult.

Complete linkage cluster analysis of compositional point counts for the Pliocene carbonates in this study distinguished six petrographic microfacies distributed between terrigenouspoor (15-20\%) and terrigenous-rich (40-60\%) end-members. Following Hayton et al. (1995) for relatively terrigenous-poor assemblages, but also extending their scheme to encompass more terrigenous ones, microfacies are given abbreviated names reflecting their dominant components (Fig. 5A), as follows: (1) detrital (av. 40-60\% siliciclastics); (2) barbital = barnacles (23\%), bivalve molluscs (22\%), and detrital grains $(37 \%)$; (3) bryotal = bryozoans $(33 \%)$ and detrital grains (32\%); (4) bimol = bivalve molluscs (35\%); (5) mixed skeletal = "pot-pourri" $(27 \%)$, bivalves $(25 \%)$, and bryozoans (14\%); and (6) barnamol = barnacles (39\%) and bivalve molluscs $(26 \%)$.

Although the different components of barbital/barnamol, bimol, and bryotal microfacies assemblages have wide depth and environmental tolerances, we use here the general environmental interpretations provided by Beu et al. (1980; barnamol), Nelson et al. (1988b; bryomol), Kamp et al. (1988; barnamol), Gillespie \& Nelson (1997; bimol), Boreen et al. (1993; bryomol), and Hayton et al. (1995; all 


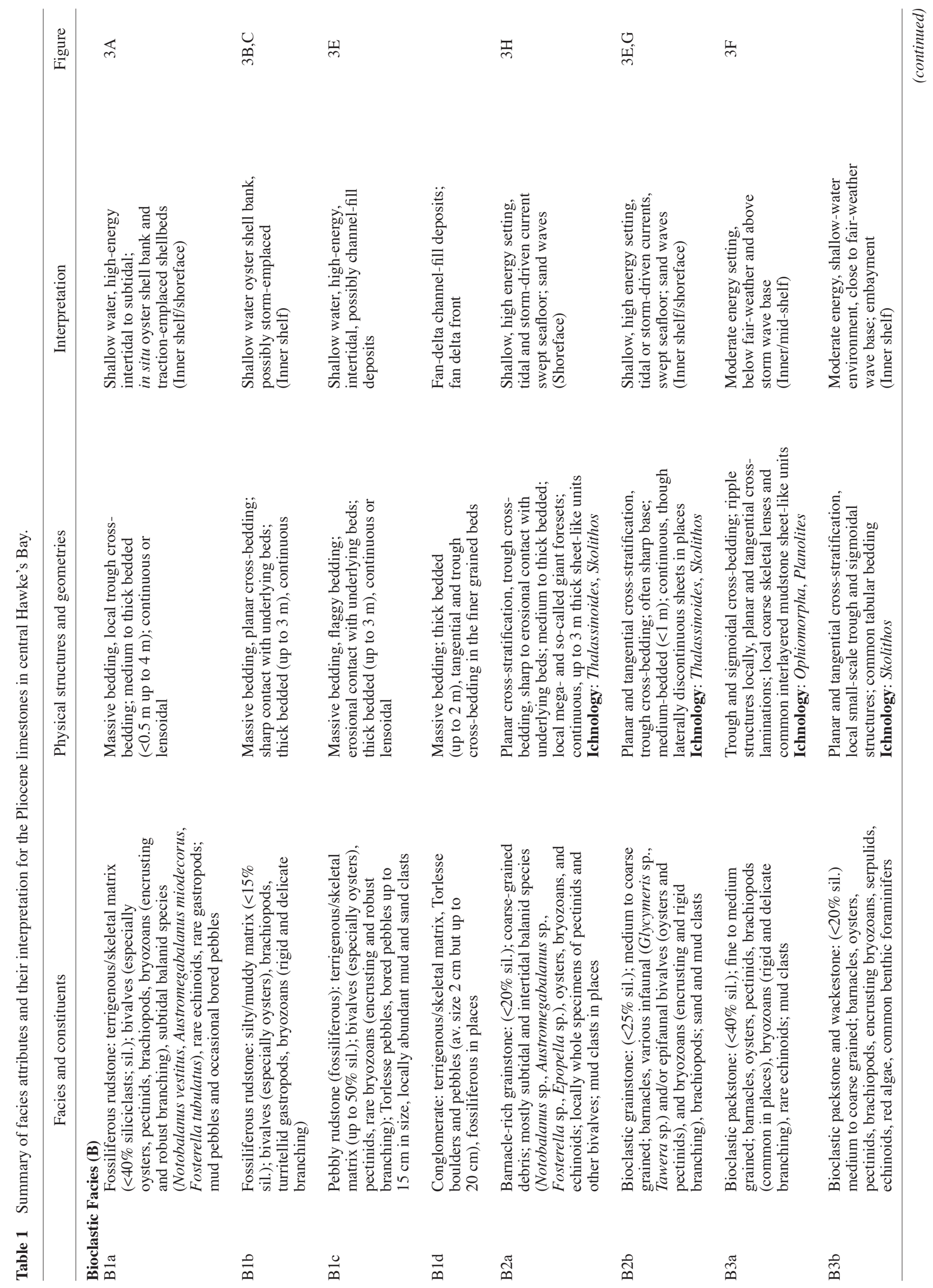


New Zealand Journal of Geology and Geophysics, 2004, Vol. 47

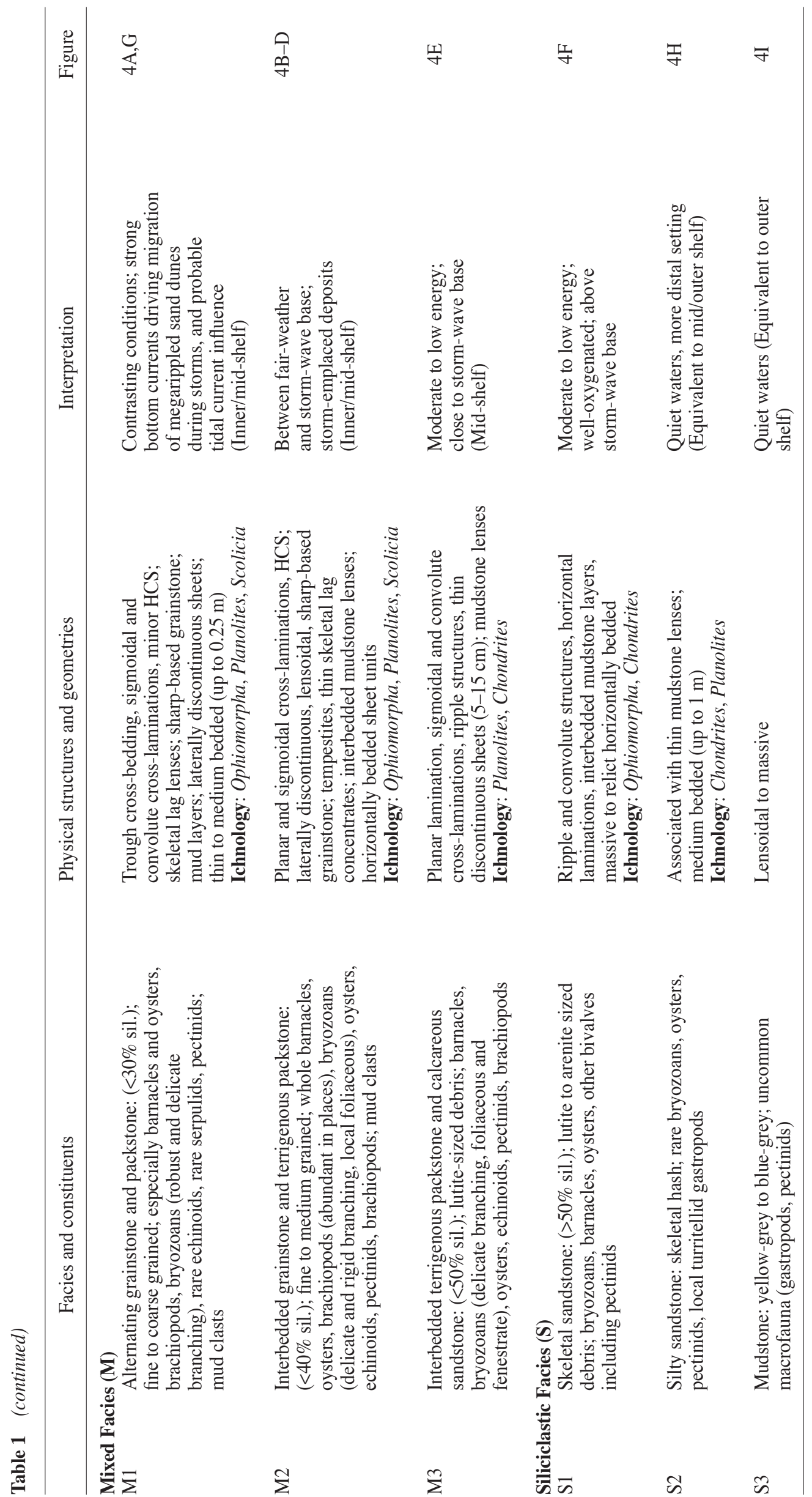


associations) as a starting basis to assist reconstruction of the depositional microfacies belts for the studied carbonates. However, siliciclastic/skeletal associations identified within reworked and redeposited deposits are most likely to represent mixed thanatocoenoses that comprise fauna from various environments.

\section{Microfacies trends with time}

Figure 5B shows the relative contributions of each microfacies assemblage to the different limestone units in central Hawke's Bay with reference to their age (Fig. 2). Despite vertical and lateral variations within each limestone unit, this simple diagram reveals the following characteristics of the Pliocene successions.

(1) Older, easternmost limestones (Kairakau/Awapapa) are compositionally distinctive from their younger more central counterparts in having a higher terrigenous content and a more diverse but dominantly calcitic fauna.

(2) There is a compositional shift towards the relatively terrigenous-free end-member over time from east to west, reaching its maximum with the Mangapanian "pure" coquina/barnacle Te Onepu Limestone.

(3) The overall terrigenous-dominated and diverse skeletal composition of Titiokura and Te Waka Formations, the latter the western time-equivalent of Te Onepu Limestone, reflect the proximity of rocky substrates and of an eroding western source area that delivered siliciclastic sand and gravel to the carbonate-rich deposits. Rocky substrates and siliciclastic input are likely to have impacted the composition of carbonate-producing biota, as suggested by the occurrence of bryozoans in the Titiokura Formation, and also sandy substrate dwellers including common infaunal aragonitic bivalves (e.g., Glycymeris, Tawera) and echinoderms in the Te Waka Formation.

(4) The youngest (Nukumaruan) limestone beds that accumulated in the central part of the narrowed forearc basin are compositionally distinctive from their older easternmost and westernmost counterparts in having a lower terrigenous content, and more variable skeletal types, usually including echinoderms, benthic foraminifers, red algae (mixed facies), and especially infaunal aragonitic bivalves.

\section{STRATIGRAPHIC ARCHITECTURE AND DIAGENESIS}

A detailed stratigraphic and diagenetic study of the Pliocene carbonate succession has shown that the Te Aute limestone units are constructed of sedimentary sequences from a few metres up to a few tens of metres thick (Caron 2002). Sequences are subdivided into systems tracts on the basis of internal stratal geometry, and interpretation of sedimentary facies and linked depositional systems between physical key surfaces. For transgressive and highstand systems tracts, surfaces arose from condensation (see below). Although, especially in the eastern sector of the study area, stratal geometries are poorly documented in a dip section due to the outcrop situation (Fig. 1), along strike (i.e., parallel to the basin axis), limestone units can be traced for several kilometres and reveal heterogeneities in the style of stratigraphic packaging.

Sequence periodicities are impossible to estimate with any confidence because of an absence of radiometric ages for the
Pliocene successions in central Hawke's Bay. Compounding the relatively poor age resolution of the limestone formations is the possibility that their successive high-frequency building sequences are not of equal duration. However, average durations of the Pliocene limestones and component sequences, estimated from several sources (Harmsen 1985; Kamp et al. 1988; Beu 1995; Field et al. 1997), range from 0.1 to $0.25 \mathrm{Ma}$ (i.e., 5th to 4th order cyclicity). Considering the average number of higher frequency sequences within the limestones (i.e., 4-12; Caron 2002), the duration of sequences would range from c. 20000 to $60000 \mathrm{yr}$, and thus would include Milankovitch precession and obliquity periodicities (i.e., 7th to 6th order cyclicity).

\section{Facies stacking and sequence stratigraphy}

Four major types of sequence motifs occur in limestone units (Fig. 6): (1) truncated sequences exhibiting a strong retrogradational (deepening-upwards) facies trend, and corresponding to sequences partly or totally amputated from, or lacking, a shoaling-upward member; (2) complete sequences having a lower retrogradational and an upper progradational (shallowing-upwards) facies trend, and typically bounded by flooding surfaces (Embry 1995; Walker 1995; Schlager 1999); (3) aggrading sequences consisting of stacked tabular subunits of comparable thickness, and bounded below by an erosional contact and above by a flooding surface; and (4) condensed sequences a few metres thick, and bounded by thin condensed horizons between successive flooding surfaces.

Identified unconformities are considered to coincide either with the transgressive surface of erosion at the base of upward-deepening deposits or regressive surfaces of erosion (Nummedal et al. 1993) at the base of forced regressive stacking facies. The absence or rarity of subaerial surfaces preserved in the stratigraphic record investigated here, and the absence of lowstand deposits partly as a result of a paucity of outcrops along- strike in a basinward direction, leave little alternative but to use the transgressive surfaces of erosion to define depositional sequences (Caron et al. 2004). Transgressive surfaces of erosion develop when sea level rises and correspond to the process of erosional translation of the shoreface profile upwards and landwards (Nummedal $\&$ Swift 1987). This process involves an intense reworking and winnowing of pre-existing deposits by the action of wave and storm currents.

The amount of erosion documented to occur during shoreface transgression ranges from a few centimetres up to 40 m (Nummedal \& Swift 1987; Walker 1995). Consequently, transgressive surfaces of erosion (TSEs) may be responsible for the removal of previous regressive systems tract (RST) sediments and surfaces developed upon them, including regressive surfaces of erosion (RSEs) and surfaces of subaerial exposure. As such, TSEs may represent significant periods of time in which several metres of sediments could have been removed. In the studied deposits, the depth of incision can hardly be confidently estimated. However, when TSEs bound several metre-thick truncated sequences, typically made up of a transgressive systems tract (TST) and part of a highstand systems tract (HST), the amount of erosion is probably in the order of a few metres at most (Caron 2002).

There is a definite geographical and time-stratigraphic pattern in the occurrence of sequence motifs. The eastern pre-Nukumaruan limestone units comprise mainly truncated 


and condensed sequences, and minor complete sequences. By contrast, western pre-Nukumaruan limestones, and Nukumaruan limestones in the central forearc area, consist of aggrading sequences, and complete sequences (Fig. 6).

Truncated sequences comprise the following facies and surfaces in ascending stratigraphic order:

(1) A basal discontinuity coincident either with a sequence boundary (subaerial exposure surface) or a TSE (Fig. 4I).

(2) A TST $(2-10 \mathrm{~m})$, consisting of a thin $(<0.2 \mathrm{~m})$ condensed bioclastic lag at the base, with abundant detrital glauconite and mud clasts, followed by either shallow-water fossiliferous and pebbly rudstone $(\mathrm{B} 1 \mathrm{a}, \mathrm{c})$, or coarse skeletal-rich cross-bedded shoreface-type facies (B3, B2a,b). These are in turn overlain by finer grained mixed carbonate-siliciclastic inner-shelf facies (M1-3).

(3) In some examples these are bounded above by a condensed horizon.

(4) The lower portion of an HST that comprises mid to outer shelf siliciclastic facies (S1, M2-M3) and is truncated by a superjacent TSE, typically penetrated by Ophiomorpha, Skolithos, and locally Thalassinoides trace fossils (Fig. 4H, 6).

TSTs of complete sequences are generally similar to those of truncated sequences. From the condensed horizon atop the TST, the overlying HST also comprises aggradational (planar and tabular bedded) mixed carbonate-siliciclastic, mid to outer shelf facies (S1, M2-3) that grade into an RST interval (Naish \& Kamp 1997). The RST commences as coarse mixed inner-shelf facies (M1-2) and passes up-section into shallow-water cross-bedded skeletal shoreface-type facies (B2a,b). Regressive deposits underlain by a sharp RSE are referred to as forced regressive systems tracts (FRST; Hunt \& Tucker 1992). RSTs and FRSTs are bounded above by either most commonly a TSE, or rarely a true sequence boundary bearing evidence of subaerial exposure (Fig. 6).

Aggrading sequences built up western Waipipian limestones (Titiokura Formation, and local channelised limestone at the base of the Te Waka Formation; Fig. 2), and include piled-up, sharp-based, cross-bedded bioclastic (M1-2, B2a) bodies separated by thin siliciclastic facies layers (S1).

Condensed sequences comprise a thin TST $(<1 \mathrm{~m})$, which corresponds to a condensed shallow-water fossiliferous to pebbly rudstone (B1c). HST and RST are typically amalgamated in shallow-water cross-bedded grainy facies (B2a) that include horizons with marine cements (Caron 2002).

\section{Stratal patterns}

In the eastern sector of the study area, there are conspicuous lateral changes in the thickness of pre-Nukumaruan limestones (e.g., Kairakau Limestone is 5-50 m thick) and in the number of fundamental building sequences from one locality to another (e.g., from 4 up to 12 in the Awapapa Limestone). Frequent perturbation in the normal development of sequences (i.e., occurrence of truncated and condensed sequences), renders the traceability of systems tracts and discontinuity surfaces difficult, even over short distances. Further complications in correlation arise from facies and diagenetic heterogeneities within component systems tracts, variations in thickness of systems tracts, and changes in the attributes of the bounding surfaces (i.e., transition from sharp to conformable, and from separate to compound surfaces).

By contrast, in the western sector of the study area, the Titiokura Formation displays a tabular geometry due to its aggrading sequential architecture. The formation extends discontinuously c. $15 \mathrm{~km}$ southward from Te Pohue (Fig. 1) and rests on a regional unconformity (Bland et al. 2004, this issue). To the north, beyond Te Pohue, the depositional architecture changes, with limestone units interdigitating with thick siliciclastic deposits that accumulated in a more basinal position (Graafhuis 2001). With the exception of the channel-hosted limestone near the base of Te Waka Formation that is only recognised at Te Pohue (Fig. 1), the Te Waka Formation consists of complete sequences of grainy to pebbly limestone-mudstone/ sandstone couplets. Although facies heterogeneities are more conspicuous than in the underlying Titiokura Formation, marker shellbeds can easily be traced allowing confident correlation.

In the Mason Ridge area, south of the Ngaruroro River (Fig. 1), the component systems tracts of the Nukumaruan sequences are easily traceable along river valleys due to little variation in their lateral thickness and their low dip, almost monoclinal structure (Caron 2002). Nukumaruan formations are more obviously cyclothemic in disposition, comprising sequential mudstone/sandstone-limestone/shellbed couplets, similar to those of the Petane Group in the Tangoio Block (Fig. 1) (Haywick et al. 1992; Haywick 2000).

\section{Skeletal microfacies within the fundamental sequence}

Within TSTs (Fig. 7), detrital and bimol microfacies commonly form the basal fossiliferous and pebbly rudstones (B1a-c), while bryotal, bimol, and in places barbital sediments form bioclastic facies (B2a-b) and overlying mixed facies (M1-3). Detrital microfacies assemblages dominate the composition of HSTs (Fig. 7). Characteristically, detrital

Fig. 3A-H Sedimentological characteristics of the Bioclastic facies (see Table 1). A, Fossiliferous rudstone of facies B1a, packed with oysters and pectinids. Note the internal planar bedding. Arrow indicates $30 \mathrm{~cm}$ long hammer (Awapapa Limestone at Te Mata Peak, V22/ 451602). B, Fossiliferous rudstone of facies B1b, packed with thin-shelled oysters. Arrow indicates hammer (Mason Ridge Formation at Torran section, V22/213593). C, Close-up of facies B1b in (B). Densely packed broken oyster shells drowned within a silty matrix. Marker pen $10 \mathrm{~cm}$ long. D, Conspicuous components of facies B1c are bored pebbles. Soft clasts (sand or mud now eroded away) are well rounded and bored on all surfaces by teardrop-shaped borings (pholads) filled with host rock-derived material (base of Kairakau Limestone at Kairakau Beach, V22/457333). E, Coarse-grained bioclastic grainstone of facies B2b overlies sharply burrowed mixed facies M2. Arrow lies at the contact and indicates trough cross-beds eroding into facies M2 (Awapapa Limestone at Te Mata Peak, V22/ 451602). Scale bar is $20 \mathrm{~cm}$ long. F, Barnacle and bryozoan-rich coarse-grained packstone of facies B3a. Note above camera cap (c. $6 \mathrm{~cm}$ across) the closely packed colonies of branching bryozoans (Te Onepu Limestone at Robottom Grave, V22/148422). G, Bi-directional cross-stratification within facies B2b (Matapiro Limestone along Ohiti Road, V21/300733). H, Coarse-grained pure coquina limestone of facies B1a. Barnacle plates are by far the dominant constituents. Note the internal deformation structure due to dewatering (Te Onepu Limestone at Te Onepu quarry, V22/198491). 


microfacies in fine-grained sediments $(\mathrm{S} 1-3)$ grade into bimol/bryotal and then into barbital assemblages in coarsening-upwards facies (M1-3). In the upper part of normal RST and FRST, barnamol and barbital assemblages dominate (Fig. 7).

\section{Diagenesis}

Caron \& Nelson (2003) and Caron et al. (in press) describe diagenetic features for the Te Aute limestones in relation to system tracts. Syn-depositional cementation (micritic and turbid cements) occurs in relatively high energy facies at specific stratigraphic positions, typically near the base of the TST, in the upper RST, and throughout the FRST. Thus, seafloor precipitation was closely associated with sequence bounding surfaces such as flooding surfaces during periods of condensed sedimentation. By contrast, destructive diagenesis (abrasion, bioerosion, dissolution) is most common in the late TST and the HST.

Patterns of cementation within eastern and western preNukumaruan limestones differ as follows: (1) most eastern limestones bear evidence of subaerial exposure to meteoric processes for a prolonged period of time, prior to burial, allowing precipitation of non-marine cements, whereas western limestones lack such pre-burial cements (see also Ricketts et al. 2004, this issue); (2) western limestones contain thick fracture-hosted burial calcite cements with high ferroan contents, believed to result from the proximity of a terrigenous source (Nelson et al. 1988a; Caron 2002), whereas in eastern limestones fracture-hosted burial cements are comparatively thin and are composed of low to moderate ferroan calcite (Caron 2002; Ricketts et al. 2004).

\section{DISCUSSION AND DEPOSITIONAL MODELS}

Changes in accommodation space, sediment supply, and hydrodynamic regime of differing amplitude and duration are critical and interdependent factors controlling the style of depositional facies stacking, the genesis of key surfaces, diagenesis, stratal geometries, and ultimately, sequence architecture (Van Wagoner et al. 1988; Vail et al. 1991; Tucker 1993; Pomar 2001). Accommodation space is wedged between the depositional surface and the wave abrasion depth where tide and storm swells have the potential to winnow away fine particles and rework coarser material. Therefore, inherited topography, tectonically and/or glacioeustatically induced sea-level changes, and climate are key factors governing changes in accommodation and stratigraphic architectures.

The efficiency of carbonate factories in cool-water environments is limited by trophic resources and siliciclastic input, especially when carbonate producers are suspension feeding (e.g., bryozoans, pectinids, and some infaunal bivalves) and/or filter feeding (e.g., barnacles, oysters) biota (Nelson 1978; Kamp et al. 1988; Nelson et al. 1988b; Henrich \& Freiwald 1995). Therefore, high-energy hydraulic conditions that prevent siliciclastic dilution and burial, and accelerate nutrient renewal, are a prerequisite to promote cool-water carbonate production of barnamol, barbital, bryotal, and bimol types. In addition, temperate carbonate sediments accumulate mainly at slower rates than do tropical equivalents, typically in the order of $2-50 \mathrm{~cm} / \mathrm{ka}$, and often $<10 \mathrm{~cm} / \mathrm{ka}$ (Nelson et al. 1988b; Haywick et al. 1992; James 1997). Because of these relatively slow overall rates of accumulation, temperate carbonate systems are particularly sensitive to relative sea-level rise, and tend to be swamped by terrigenous sediments as current velocity decreases with increasing water depth. This contrasts with tropical carbonate systems where sedimentation rates are generally high enough to keep up with and even exceed the rates of relative sea-level rise (Emery \& Myers 1996). Therefore, during periods of limestone development in central Hawke's Bay, an equilibrium between subsidence and eustasy must have been reached in order for the accumulation of carbonate biota to keep up with relatively slow rates of sea-level changes at the production sites.

Pliocene-Pleistocene limestone-bearing successions in Hawke's Bay result from the stacking of sedimentary sequences with recurring facies architectures inferred to have been produced in response to high-frequency glacioeustatic oscillations (Haywick et al. 1992; Caron 2002; Caron et al. 2004; in press). However, the significant facies and architectural contrasts between eastern, central, and western limestone formations suggest deposition in different morphological and geotectonic systems (Fig. 8).

In the east, areas of both anomalously thin and anomalously thick limestones point to uneven seafloor topographies. As a consequence, evidence of some relative sea-level variations may have only been recorded in restricted portions of the carbonate realm where sediments could be locally accommodated. Elsewhere, such evidence may be

Fig. 4A-I Sedimentological characteristics of the Mixed facies (see Table 1). A, Interbedded grainstone and packstone of facies M1. Coarse-grained sediments exhibit tangential and sigmoidal cross-stratification in sets $0.5-1.0 \mathrm{~m}$ thick, interpreted as prograding sand waves (Awapapa Limestone at Pukekura, V22/292475). B, Interbedded grainstone and terrigenous packstone arranged in horizontal bed sets, $0.3 \mathrm{~m}$ thick (facies M2). Dashed line indicates sharp contact interpreted as a ravinement surface underlying a massive $2-3 \mathrm{~m}$ thick shellbed within the Mason Ridge Formation at Pakihirua (V22/188548). C, Interbedded coarse-grained skeletal-rich trough cross-beds and finer grained terrigenous packstones forming facies M2. Burrows (arrowed) within terrigenous facies are filled with coarse material from overlying sharp-based grainstone. Scale bar $14 \mathrm{~cm}$ (Awapapa Limestone at Te Mata Peak, V22/451602). D, Dewatering structures in mixed carbonate-siliclastic sediments (facies M2). Hammer $30 \mathrm{~cm}$ long (Kairakau Limestone at Koanui, V22/460504). E, Medium-scale hummocky cross-stratification (black arrow) in planar-laminated calcareous sands (facies M3). Ophiomorpha burrows (white arrows) within fine-grained deposits (Te Waka Formation at The Gorges section, V20/188007; Fig. 1). F, Horizontal and low-angle planar crossstratification in fine to medium grained calcarenites (facies M3; Rotookiwa Limestone at Lonely Man section, V22/228495). G, Superposed tabular bed sets with internal planar cross-stratification (facies M1; Kairakau Limestone at Kairakau Beach, V22/457333). H, Ravinement surface coincident with a transgressive surface of erosion (arrows) places coarse-grained sediments of facies B2b (above) in direct and erosive contact with facies S2 (below). Below the ravinement surface, Thalassinoides burrows penetrate downward into siltstone. They are filled with carbonate sand from the overlying unit (dashed lines). Kairakau Limestone at Te Mata Peak (V21/452597). Camera lens cap for scale. I, A surface burrowed by Skolithos (black arrow) and Scolicia (dashed line) is interpreted as a transgressive surface of erosion marking the boundary between coarse bioclastic sediments of facies B3a above and massive mudstone (facies S3) below (Kairakau Limestone at Kairakau Beach, V22/457333). Scale length on tape measure is c. $5 \mathrm{~cm}$. 
A

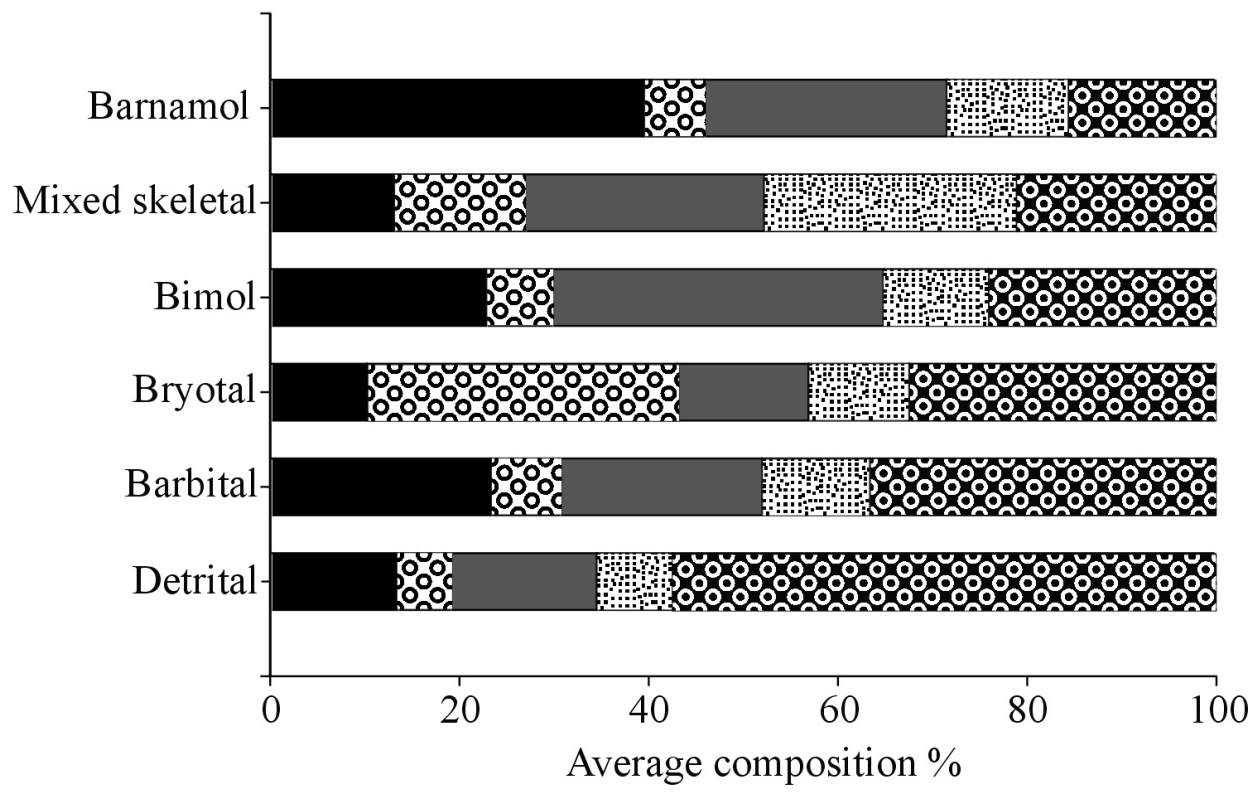

Barnacles

Bivalves

\%\% Siliciclasts

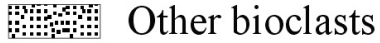

B

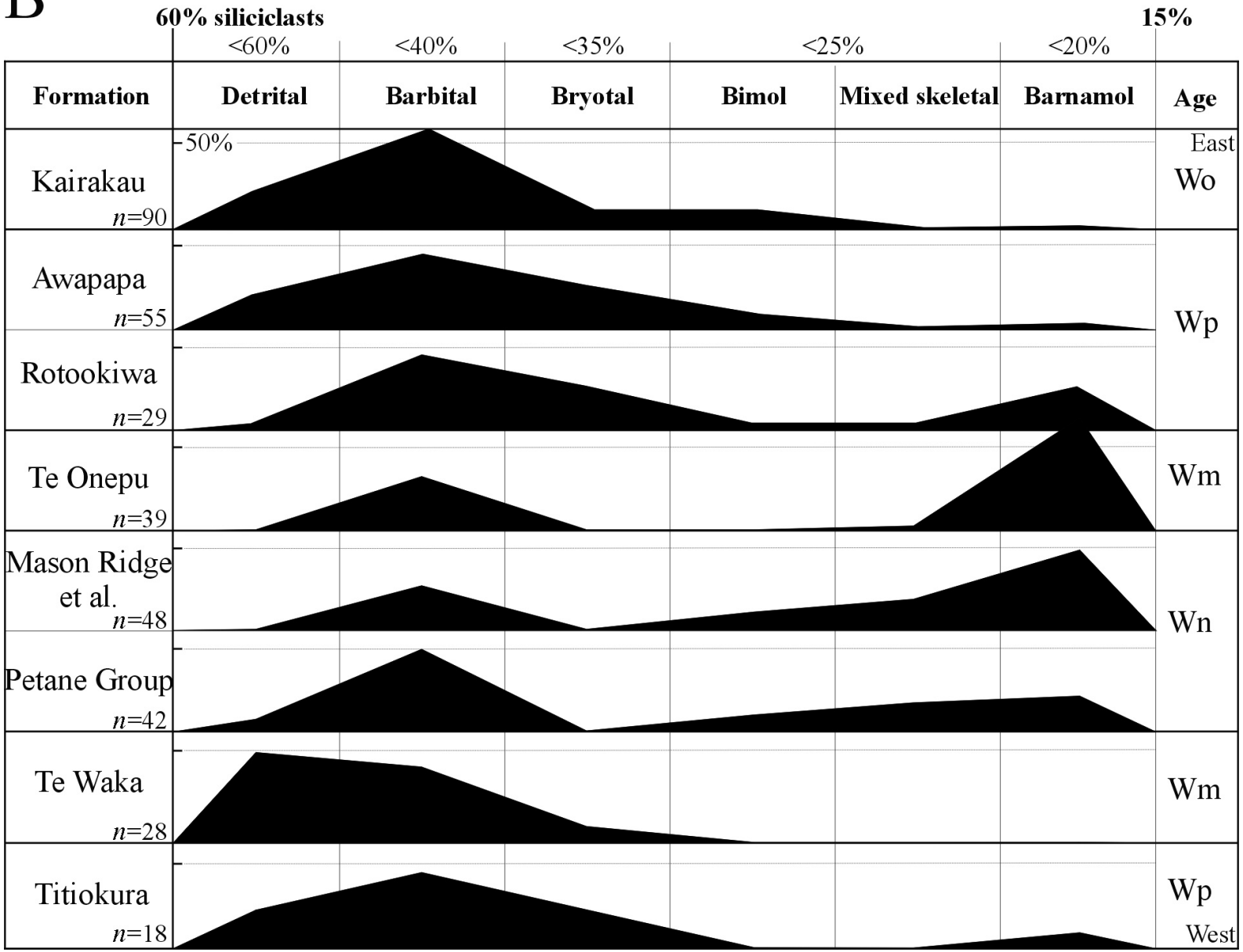

Fig. 5 A, Mean skeletal and siliciclastic composition of the six microfacies assemblages identified in the Pliocene limestone samples $(n=351)$ of central Hawke's Bay. B, Relative contribution from each of the mixed carbonate-siliciclastic microfacies assemblages to the different limestone units arranged vertically from east to west in relation to their age (Mason Ridge et al. includes samples from Mason Ridge Formation, Pakipaki Limestone, and Scinde Island Limestone; Fig. 2). 


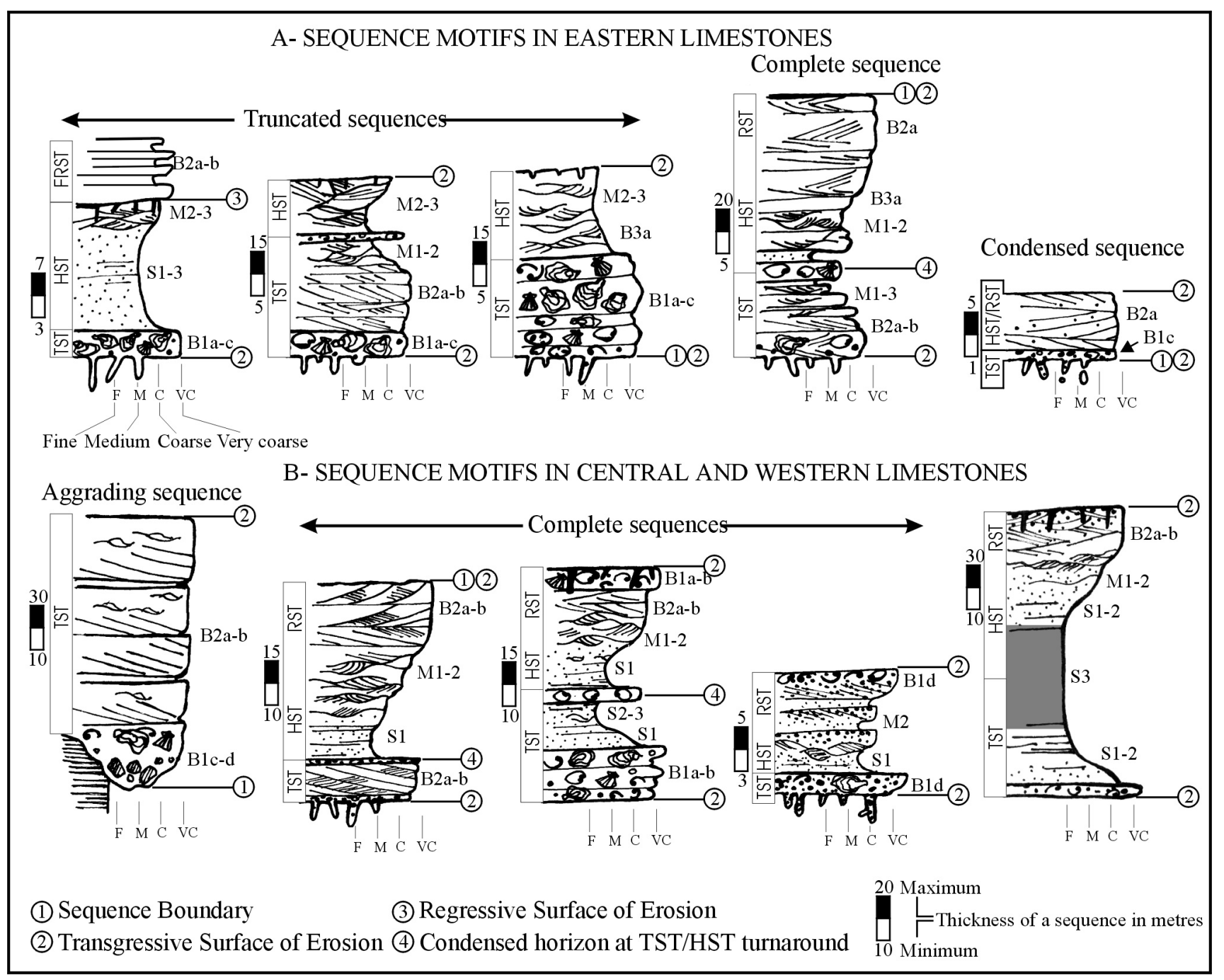

Fig. 6 Comparison of sequence motifs for the Pliocene limestones from the eastern and western/central sides of the forearc basin in central Hawke's Bay showing vertical sedimentary facies (Table 1) successions within the component systems tracts, and the nature of physical surfaces bounding them. Sequence motifs are based on observed lithologies. TST, transgressive systems tract; HST, highstand systems tract; RST, regressive systems tract; FRST, forced regressive systems tract.

missing or more subtle, resulting in truncated or amalgamated sequences.

The complex stratigraphic architecture of eastern preNukumaruan limestones is considered to have arisen due to differential uplift/subsidence forced by tectonics that produced: (1) local arches where a high-energy hydraulic regime favoured mainly siliciclastic-free barnacle factories and condensation; and (2) depressions where sediments delivered from neighbouring factories could be accommodated allowing preservation of a higher number of sequences (Kamp \& Nelson 1987; Vitale 1998; Caron 2002).

The stratigraphic architecture and stratal geometries of western pre-Nukumaruan and central Nukumaruan limestones are indicative of deposition on homoclinal or distally steepened flattish ramps, affected by tidal and storm currents. The variability in nature and distribution of facies belts between the depositional settings is also considered to reflect differences in hydraulic regime and dilution by siliciclastic sands. Depositional models envisaged for the Pliocene limestones are presented below, and schematically illustrated in Fig. 8, 9, and 10.

\section{Eastern setting}

The depositional model suggested for the Te Aute carbonates near the eastern side of the forearc shares many attributes with isolated structurally controlled platforms (Fig. 8,9) that support major carbonate production (e.g., Southeast Asia; Emery \& Myers 1996). Characteristics of such isolated platforms are that they are generally siliciclastic poor (best exemplified in the central Hawke's Bay situation by the Rotookiwa, Te Onepu, and Pakipaki Limestones; Fig. 2), and they lack the close interrelation with continent-derived sediments that typify continent-attached platforms (Dorsey \& Kidwell 1999; Haywick 2000; Brachert et al. 2003). Furthermore, this model contrasts with the low-gradient carbonate ramps suggested for many non-tropical carbonates, exemplified by the modern shelf of southern Australia (James et al. 1994), the modern West Shetland Shelf (Light \& Wilson 1998), and other ancient tideand storm-dominated low-gradient carbonate shelf settings. Here, particles mainly accumulate in the form of variably extensive sheet-like or tabular bodies (Nelson 1978; Boreen \& James 1995; Lukasik et al. 2000) on the mid and outer shelf where the prevailing current regime allows deposition. 


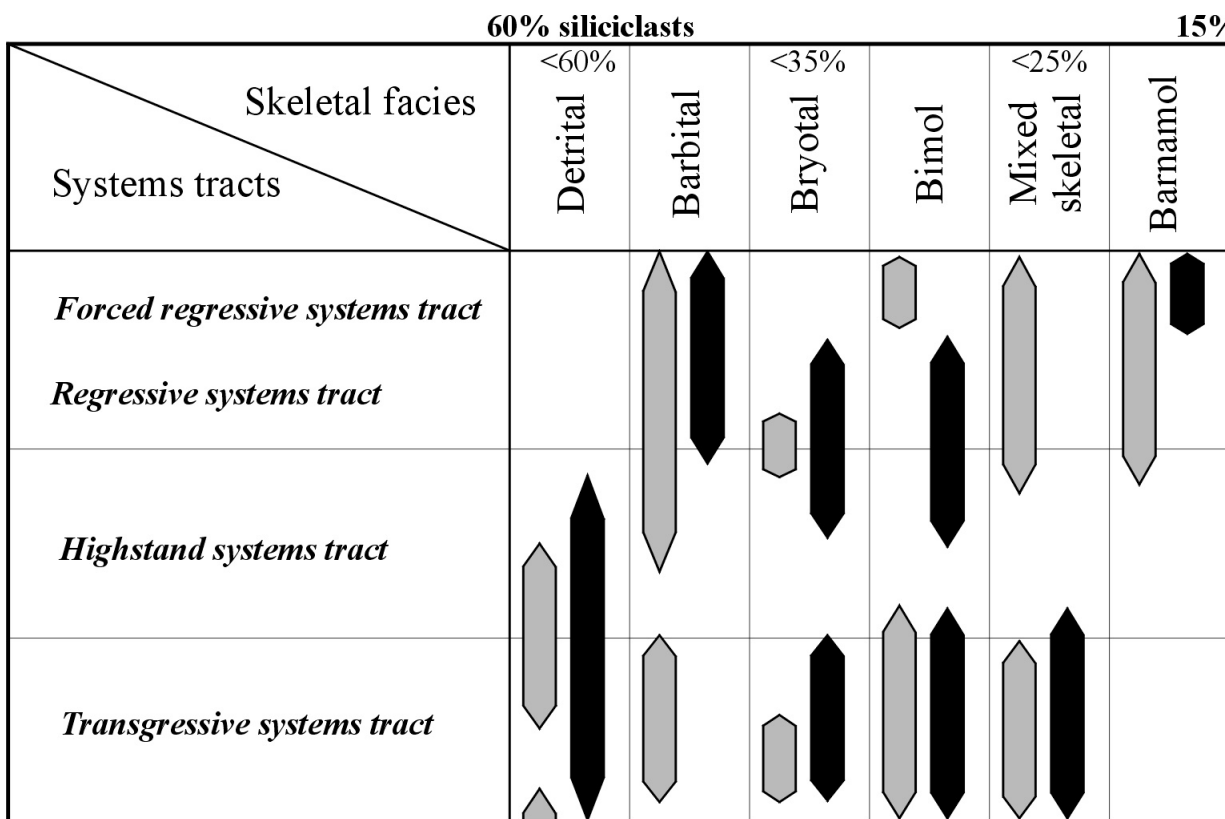

Fig. 7 Relative vertical distribution of petrographic microfacies assemblages within the component systems tracts of Pliocene sequences with reference to the locus of deposition.

$\bigcap$ Up-dip section or shallow water Down-dip section or deeper water

The eastern part of the study area has been subjected to thrust-related folding since at least the early Pliocene, resulting in a number of asymmetric anticlines and synclines generally trending northeast-southwest. Kamp et al. (1988) and Beu (1995) inferred that syn-sedimentary tectonic highs were the major sites of carbonate formation during the Pliocene because the hydraulic regime atop the structures forced siliciclastic sand by-passing. The depositional system can be characterised as neighbouring tide-dominated carbonate factories developed upon and about actively growing thrustcored antiforms (Fig. 8) cut by a complicated network of channels that constrained tidal flows (Fig. 9). It is inferred that limestone started to accumulate after the forearc basin margins had probably experienced regressive conditions (i.e., shallowing either tectonically or glacioeustatically forced, or both).

Typically, within the building sequences of the limestones, bimol precedes bryotal and barbital microfacies in the lower TSTs (Fig. 7), suggesting that the balanid facies would not develop until a suitable shelly substrate had been produced or exhumed by bottom swells (Kamp et al. 1988; Eyles \& Lagoe 1989; Brachert et al. 2003). During relative sea-level fall, lowering of the abrasion wave base and subsequent winnowing of siliciclastics may also have triggered balanid factories in RSTs by exhuming coarse coquina substrate that attracted barnamol communities. Indeed, winnowing must have been maximal on top of antiforms once they had come under the influence of high-energy tidal and storm currents. This would have also induced condensation and enhancement of seafloor cementation. In the absence of organisms capable of constructing wave-resistant structures, skeletons of dead organisms were rapidly shed off the antiform tops and accumulated in the form of prograding dunes on the antiform flanks. The fragility and low resistance to abrasion of barnacle plates suggest that coarse bioclastic dunes accumulated a short distance away from living sites (Buckeridge 2000) (Fig. 9).

\section{Western setting}

By contrast with their eastern counterparts, the depositional system envisaged for the western mixed carbonate-siliciclastic accumulations, to the south of Te Pohue (Fig. 1), is one of a narrow continent-attached shelf swept by tidal and storm currents periodically supplied with terrigenous sediments (Fig. 8, 10). The aggradational stratal pattern of the Waipipian Titiokura Formation in the vicinity of Te Pohue, and its relatively low siliciclastic content, are similar to cool-water carbonates deposited on slow subsiding shallow gradient shelves attached to a low-elevated landmass (James et al. 1994; Boreen \& James 1995). Distribution of Pliocene strata in central Hawke's Bay on the basis of mapping (Graafhuis 2001) and electric logs from exploration drillholes (Field et al. 1997) suggest that siliciclastic sands were deposited in the

Fig. 8 Conceptual model of forearc basin seaway (the Ruataniwha Strait of Beu 1995) in the early late Pliocene (late Mangapanian) (see Fig. 1,2) showing that a siliciclastic-poor continent-detached carbonate platform in the east co-evolved with a mixed carbonate-siliciclastic continent-attached carbonate platform on the basinal margins in the west (i.e., south of Te Pohue; Fig. 1). Stratigraphic columns point out differences in facies composition and stratigraphic architectures between time-equivalent limestones. See Fig. 9 and 10, respectively, for details about the depositional environments of limestones on the eastern and western margins of the forearc basin seaway. Titiokura/Te Waka Formations from The Gorges section (V20/188007); Rotookiwa Limestone from Horse Shoe section (V22/345586); Te Onepu Limestone from Bee Swarm section (V22/193484) (all located in Fig. 1). Basement structure modified from Erdman \& Kelsey (1992) and Croft Exploration Ltd (1992). 


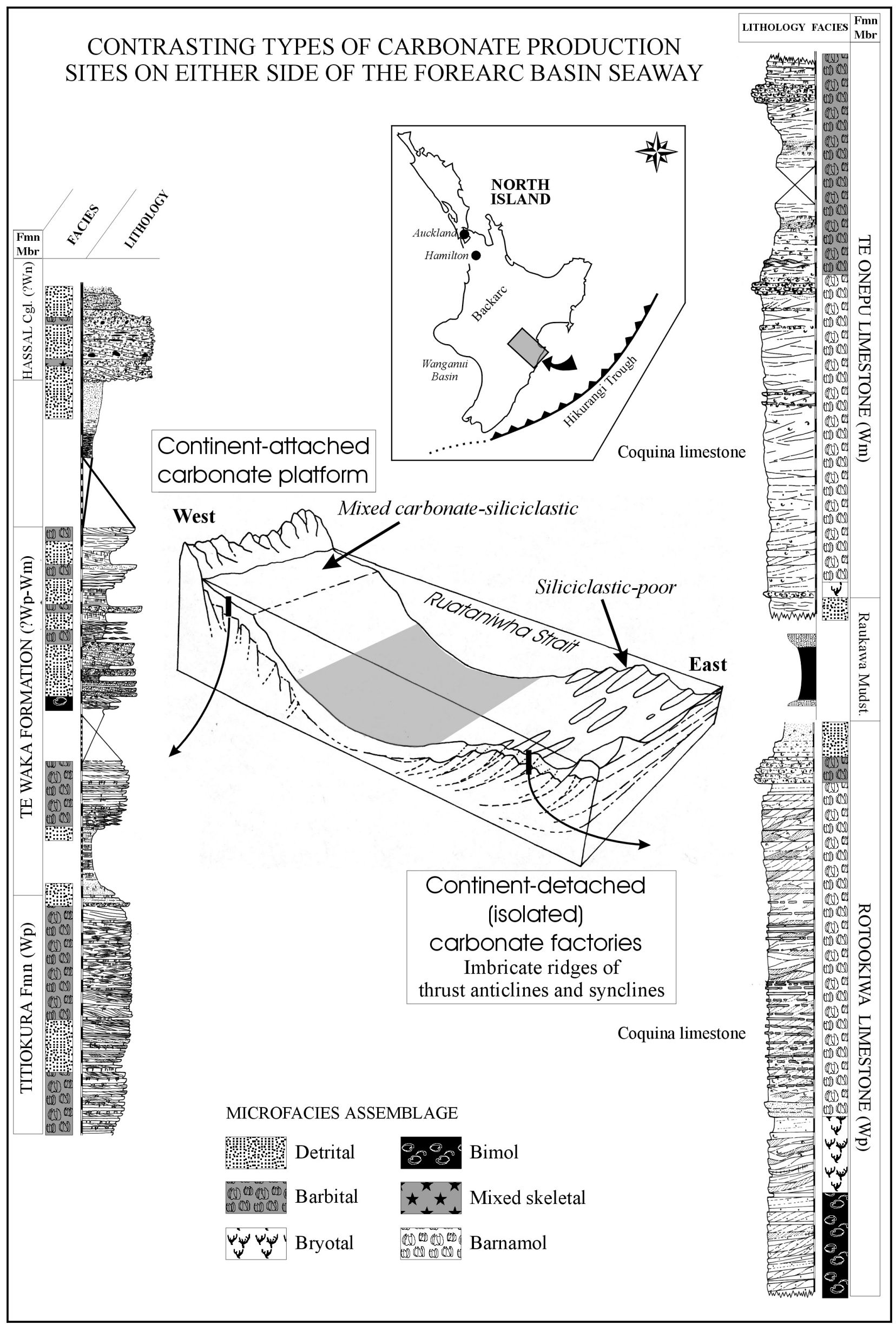




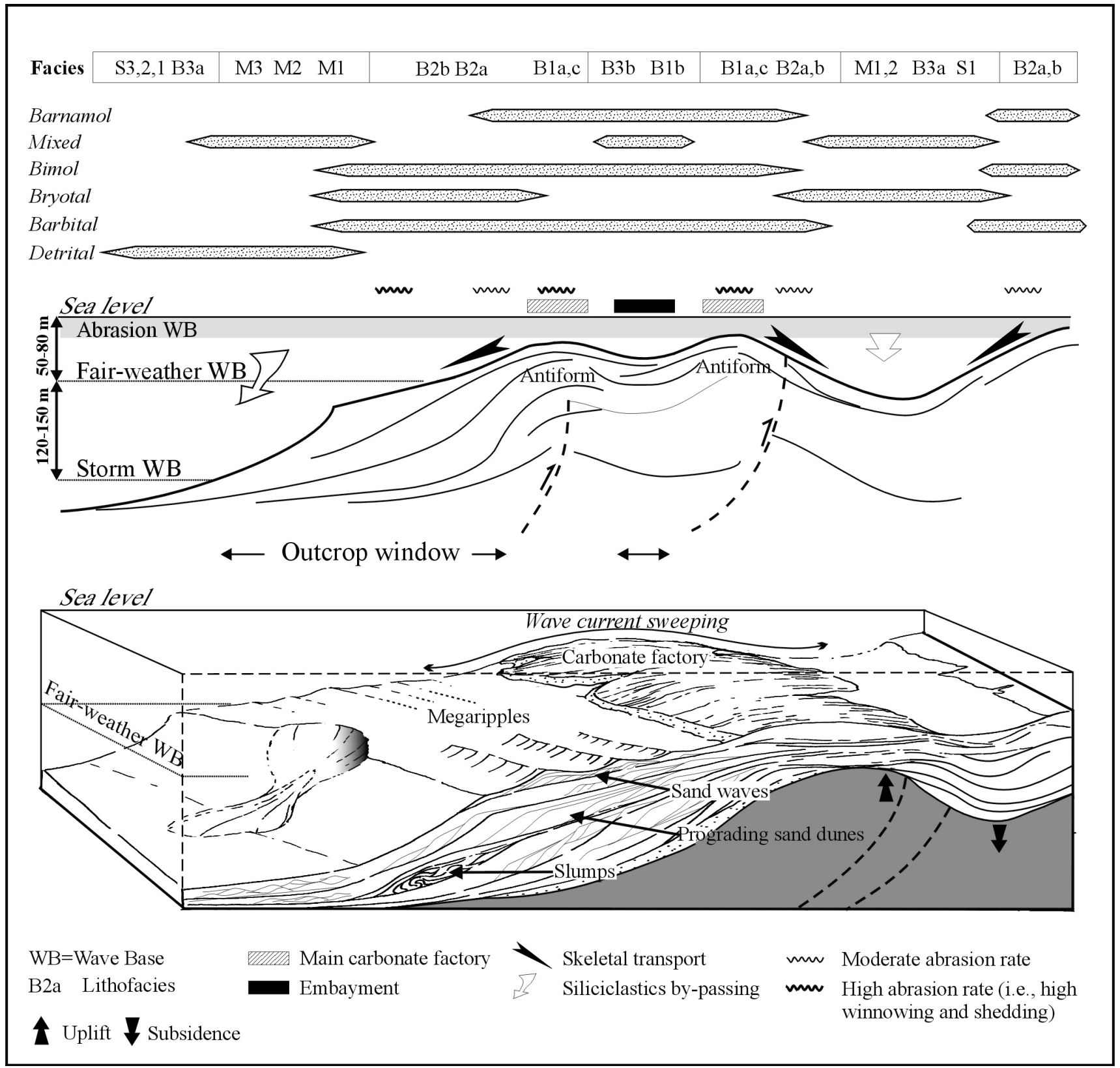

Fig. 9 Depositional model of isolated cool-water carbonate platform proposed for pre-Nukumaruan limestones in the eastern sector of central Hawke's Bay showing relationships between carbonate sediment facies (see Table 1), distribution of microfacies assemblages, hydrodynamic conditions, and sedimentary bedforms/structures in the vicinity of structural antiforms.

central part of the basin during carbonate accumulation on the shelf. It is likely that the carbonate factories were isolated from siliciclastic fluxes linked more to channels and incised valleys (Fig. 10). Strong tidal currents and elevated nutrient supply probably promoted both bryozoan and barnacle growth upon coastal or inner to mid shelf rocky shoals (Fig. 10). This would have been comparable to environments of carbonate production on the shelf west of Scotland (Scoffin 1988). Progressive uplift of the adjacent landmass during the Mangapanian led to an increase in sand and gravel sized siliciclastic inputs to the shelf that strongly influenced the composition and production rates of carbonate biota. Although balanids persisted in the composition of the now mixed carbonate-siliciclastic limestones, skeletons also included sand-dwelling aragonitic bivalves and echinoderms. The continental shelf adjoining Otago Peninsula (eastern South Island, New Zealand) constitutes a possible modern analogue of the depositional model proposed here (Andrews 1973). In this area, the relatively narrow (11-30 km in width) shelf off the Otago Peninsula abuts exposed basement (schist) presently supplying the detrital sand and pebble fraction deposited in inner to mid shelf settings. Gravelly sediments rich in skeletal debris, like bryozoans (Andrews 1973; Probert et al. 1979), cover the middle and outer shelf farther seaward.

Limited precipitation of pre-burial meteoric or mixed marine-meteoric cements within the Titiokura and Te Waka Formations indicate: (1) little to no subaerial exposure for 


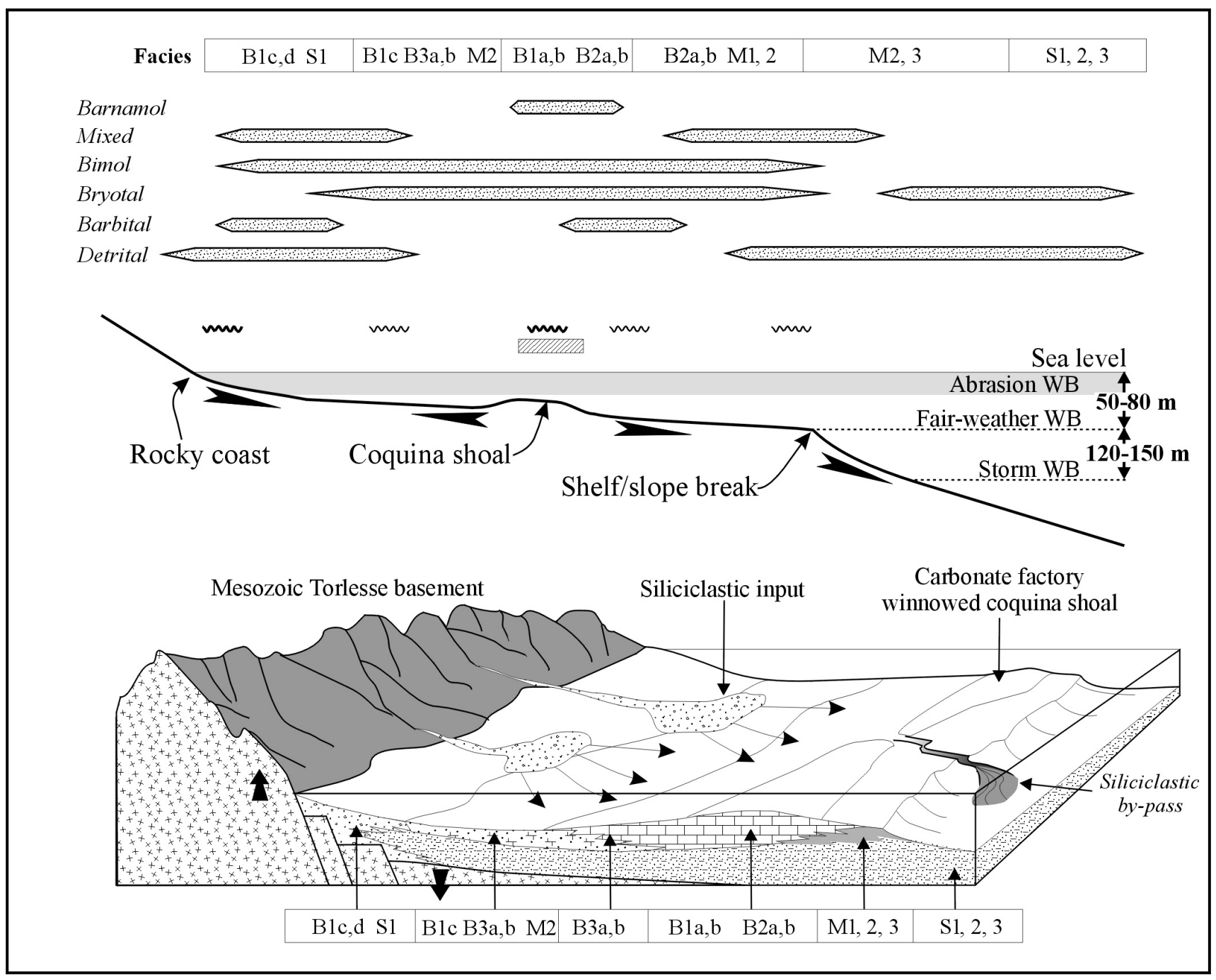

Fig. 10 Depositional model of cool-water carbonate platform attached to a landmass envisaged for pre-Nukumaruan limestones deposited on the western margin of the forearc basin in central Hawke's Bay. The model applies to limestone units deposited south of Te Pohue (see text). See Fig. 9 for the key to symbols.

prolonged periods of time, due to probable continuous subsidence of the shelf; and (2) that the adjacent landmass, a potential source of meteoric fluids, was not elevated enough to drive significant gravity-driven flows within the basin (Ricketts et al. 2004).

In the south, during latest Nukumaruan times, sedimentation was strongly controlled by movements on strikeslip and reverse faults bounding downwarped and uplifted basement blocks, respectively. Thick mudstone and siltstone beds accumulated in structural troughs (Ohara Depression), whereas carbonates (e.g., Sentry Box Limestone, Kereru Limestone) formed in shallow waters on top of uplifted blocks (Cashman et al. 1992; Erdman \& Kelsey 1992), resembling the growth fold sites of carbonate production to the east during the Mangapanian.

\section{Central setting}

Limestone sheets of Nukumaruan age are characterised by a higher content of carbonate mud, infaunal aragonitic bivalves, and indicators of possibly warm-temperate shallowwater environmental conditions, including micritisation and micritic microbial coatings. Benthic foraminifers and red algal skeletons are also more abundant, but barnacles, bivalves, and bryozoans remain persistent skeletal components (Caron 2002). The abundance of aragonitic components within these carbonates, compared with older barnacle-epifaunal calcitic mollusc-dominated pre-Nukumaruan carbonates, indicates that the conditions that prevailed during early-mid-Pliocene times evolved with respect to environmental factors, such as water depth, substrate, and current velocity. Higher sedimentation rates of fine terrigenous material probably favoured colonisation of the seafloor by increased quantities of aragonitic bivalves by the late Pliocene (Beu et al. 1980; Haywick 1990). Nukumaruan limestone units in central Hawke's Bay are interpreted to have formed in less open marine environments than their older counterparts, possibly in embayed coastline settings on a shallow homoclinal ramp periodically swept by storm waves and tidal currents (Beu et al. 1980; Haywick 1990; Caron 2002). The cyclothemic nature of the Nukumaruan formations has been attributed to recurring sea-level fluctuations forced by inferred short-term orbital perturbations (Haywick et al. 1992). 


\section{CONCLUSIONS}

The central Hawke's Bay study area represents about onethird of the extent of a forearc basin exposed above sea level. It provides a record of the differential emergence of the forearc basin margins and subsidence of its central part, the timing of successive carbonate deposition periods, and of uplift above sea level, spanning the interval from the early Pliocene to earliest Pleistocene (late Opoitian to late Nukumaruan). The compressional system consisted of a rising accretionary complex of deformed Cenozoic sediments to the southeast and a frontal arc of Mesozoic basement rocks to the west (Ballance 1993). These contrasting morphodynamic conditions translated to the episodic development during regressive conditions (Caron 2002) of co-evolving, but morphologically distinct, cool-water carbonate "platforms" on either side of the basin.

The continent-detached depositional setting for the coolwater pre-Nukumaruan limestones to the east is envisaged to be one of isolated, siliciclastic-poor, submarine antiforms and ridges that hosted carbonate factories. Around and about these submarine highs, some of which may have locally become

Table 2 Comparison of morphodynamic and genetic factors, stratal geometries, and facies typical of continent-attached and continentdetached carbonate platforms as envisaged for the Pliocene limestones in central Hawke's Bay.

\begin{tabular}{|c|c|c|}
\hline $\begin{array}{l}\text { Facies attributes: } \\
\text { Morphodynamic and genetic factors }\end{array}$ & $\begin{array}{l}\text { Landmass-attached carbonate platform } \\
\text { (Western sector of the forearc basin) }\end{array}$ & $\begin{array}{l}\text { Landmass-isolated carbonate platform } \\
\text { (Eastern sector of the forearc basin) }\end{array}$ \\
\hline Morphological system & $\begin{array}{l}\text { Homoclinal ramp, distally steepened ramp } \\
\text { embayed coastal setting }\end{array}$ & $\begin{array}{l}\text { Parallel anticlines and synclines } \\
\text { neighbouring flat-topped antiforms }\end{array}$ \\
\hline Inherited topography & $\begin{array}{l}\text { Low gradient flat shelf abutting against } \\
\text { subdued or elevated landmass }\end{array}$ & $\begin{array}{l}\text { Uneven antecedent surface, troughs } \\
\text { and growth folds }\end{array}$ \\
\hline Tectonic setting & $\begin{array}{l}\text { Subsiding edge of frontal arc; deformation } \\
\text { controlled by movements on faults bounding } \\
\text { basement blocks }\end{array}$ & $\begin{array}{l}\text { Rising accretionary complex of forearc; } \\
\text { upthrust cored structures }\end{array}$ \\
\hline Glacioeustatic imprint & \multicolumn{2}{|c|}{$\begin{array}{l}\text { Creation or destruction of accommodation space; forces cyclicity (i.e., recurrence of stacking } \\
\text { patterns) and genesis of unconformities (flooding surfaces, regressive surfaces, and subaerial } \\
\text { exposure surfaces) }\end{array}$} \\
\hline Syn-tectonic influence & $\begin{array}{l}\text { Possible creation of local depocentres, } \\
\text { mainly slow creation of accommodation } \\
\text { space (i.e., subsidence) }\end{array}$ & $\begin{array}{l}\text { Forces arch development or increases } \\
\text { accommodation space (i.e., depression); } \\
\text { generates or enhances unconformities; } \\
\text { differential preservation of sequences; } \\
\text { local exposure of antiform tops }\end{array}$ \\
\hline Sequence motifs - stratal patterns & $\begin{array}{l}\text { Aggrading sequences and complete } \\
\text { sequences }\end{array}$ & $\begin{array}{l}\text { Mainly truncated and condensed sequences; } \\
\text { complete sequences uncommonly preserved }\end{array}$ \\
\hline Stratigraphic architecture & $\begin{array}{l}\text { Sheet-like and tabular geometries of } \\
\text { limestones allow traceability of marker } \\
\text { beds and unconformities }\end{array}$ & $\begin{array}{l}\text { Complex as a result of uneven depositional } \\
\text { surfaces and syn-tectonism; rapid lateral } \\
\text { changes in thickness, facies, and syn-depositional } \\
\text { diagenesis of limestones, building sequences } \\
\text { and component systems tracts }\end{array}$ \\
\hline Hydrologic regime & $\begin{array}{l}\text { High energy, tide and storm dominated } \\
\text { on the open shelf in coastal or inner to } \\
\text { mid-shelf rocky areas; lower energy in } \\
\text { shallow-water embayment }\end{array}$ & $\begin{array}{l}\text { High energy, tide and storm dominated; } \\
\text { submarine topography causes the current } \\
\text { regime to rapidly change from erosional to } \\
\text { depositional in a general down-slope direction }\end{array}$ \\
\hline Siliciclastic input & Moderate to high & Low \\
\hline Substrate & $\begin{array}{l}\text { Locally rocky, gravelly, sandy and shelly } \\
\text { in places; muddy in embayments }\end{array}$ & Shelly to sandy in a down-dip direction \\
\hline Skeletal carbonate components & $\begin{array}{l}\text { Epifaunal and infaunal bivalves, } \\
\text { balanids, bryozoans, echinoderms }\end{array}$ & Balanids, epifaunal bivalves, bryozoans \\
\hline Skeletal mineralogy ${ }^{1}$ & LMC-IMC-HMC, and common aragonite & Dominantly LMC, little HMC and aragonite \\
\hline \multicolumn{3}{|l|}{ Pre-burial diagenesis: } \\
\hline Seafloor cementation & \multicolumn{2}{|c|}{ Restricted to high-energy condensed horizons in both systems } \\
\hline Meteoric cementation & $\begin{array}{l}\text { If prolonged exposure of the shelf or } \\
\text { sourced from the landmass elevated enough } \\
\text { to develop an extensive meteoric wedge; } \\
\text { enhanced by higher aragonitic content }\end{array}$ & Only if prolonged exposure of antiform tops \\
\hline
\end{tabular}

${ }^{1} \mathrm{LMC}$ : low-Mg calcite (<4 mol\% $\mathrm{MgCO}_{3}$ ); IMC: intermediate-Mg calcite (4-12 mol\% $\left.\mathrm{MgCO}_{3}\right)$; HMC: high-Mg calcite (>12 mol\% $\left.\mathrm{MgCO}_{3}\right)$. 
emergent forming promontories or islands, accelerated tidal currents actively transported sediments. Dunes migrated under the influence of storm currents in a down-dip direction off the antiform tops, frequently forming large skeletal banks. Thus, it is inferred that the submarine topography caused the current regime to change from erosional to depositional, in a general down-slope direction.

In contrast, the depositional setting for the western pre-Nukumaruan limestone occurrences corresponded to continent-attached carbonate platforms. The monoclinal and locally cyclothemic disposition of the successions, together with their moderate to high contents of Torlesse basementderived siliciclastics, indicate that carbonate sediments probably formed and accumulated on a shallow low gradient shelf regularly provided with terrigenous detritus.

In the central forearc, Nukumaruan cyclothemic limestones are interpreted to have developed in coastal embayed settings on a flat homoclinal ramp attached to a landmass.

The limestones are constructed of metre-scale sequences whose accumulation is considered to originate from a strong interplay between the creation of accommodation space and sediment supply, both controlled by the combined effects of tectonically and glacioeustatically driven processes. Field evidence suggests that differing topographical and geotectonic contexts resulted in differences in stratal geometries, stacking patterns, siliciclastic inputs, and carbonate facies types between the eastern and western carbonate platforms. Some of these differences are summarised in Table 2.

Not only does the Hawke's Bay forearc basin setting yield a unique example of a siliciclastic-poor isolated cool-water carbonate platform, but by hosting a contemporaneous and local example of a continent-attached mixed carbonatesiliciclastic platform it also provides an opportunity to assess how geotectonic (e.g., inherited topography and subsidence) and genetic factors (e.g., hydrodynamics, nutrient, and siliciclastic supplies) interact to influence limestone development. The proposed depositional model may prove a useful alternative to help interpret cool-water carbonates formed elsewhere in similar compressional tectonic settings.

\section{ACKNOWLEDGMENTS}

The authors express their appreciation to Alan Beu (Geological \& Nuclear Sciences (GNS), Lower Hutt) for field guidance and expertise on Pliocene macrofauna, and to Arne Pallentin, Dave Francis, Kyle Bland, and Viviane Simard-Caron for field assistance and fruitful discussions about the stratigraphy of the Pliocene limestones in eastern North Island. The final version of this paper benefited from constructive review comments by Greg Browne (GNS, Lower Hutt) and Doug Haywick (University of South Alabama, USA). Funding assistance for this study came from Marsden Fund (Royal Society of New Zealand) contract UOW801 and Foundation for Research, Science and Technology contract UOWXO301 to the University of Waikato.

\section{REFERENCES}

Andrews, P. B. 1973: Late Quaternary continental shelf sediments off Otago Peninsula, New Zealand. New Zealand Journal of Geology and Geophysics 16: 793-830.

Ballance, P. F. 1993: The New Zealand Neogene forearc basins. In: Ballance, P. F. ed. Sedimentary basins of the world, 2. South Pacific sedimentary basins. Amsterdam, Elsevier. Pp. 177-193.
Betzler, C.; Brachert, T. C.; Braga, J-C.; Martin, J. M. 1997: Nearshore, temperate, carbonate depositional systems (lower Tortonian, Agua Amarga Basin, southern Spain): implications for carbonate sequence stratigraphy. Sedimentary Geology 113: 27-53.

Beu, A. G. 1995: Pliocene limestones and their scallops. Institute of Geological \& Nuclear Sciences Monograph 10. Lower Hutt, New Zealand, Institute of Geological \& Nuclear Sciences Ltd. 243 p.

Beu, A. G.; Grant-Taylor, T. L.; Hornibrook, N. de B. 1980: The Te Aute limestone facies, Poverty Bay to northern Wairarapa. Wellington, New Zealand, Department of Scientific and Industrial Research. 36 p.

Bland, K. J.; Kamp, P. J. J.; Pallentin, A.; Graafhuis, R.; Nelson, C. S.; Caron, V. 2004: The early Pliocene Titiokura Formation: stratigraphy of a thick, mixed carbonate-siliciclastic shelf succession in Hawke's Bay Basin, New Zealand. New Zealand Journal of Geology and Geophysics 47: 675-695 (this issue).

Boreen, T. D.; James, N. P. 1995: Stratigraphic sedimentology of Tertiary cool-water limestones, SE Australia. Journal of Sedimentary Research B65: 142-159.

Boreen, T. D.; James, N. P.; Heggie, D.; Wilson, C. 1993: Surficial cool-water carbonate sediments on the Otway continental margin, southeastern Australia. Marine Geology 112: 35-56.

Brachert, T. C.; Forst, M. H.; Pais, J. J.; Legoinha, P.; Reijmer, J. J. G. 2003: Lowstand carbonates, highstand sandstones? Sedimentary Geology 155: 1-12.

Buckeridge, J. 2000: Cirripedes as palaeocological indicators in the Te Aute lithofacies limestone, North Island, New Zealand. Memoirs of the Queensland Museum 42: 221-225.

Caron, V. 2002: Petrogenesis of Pliocene limestones in southern Hawke's Bay, New Zealand: a contribution to unraveling the sequence stratigraphy and diagenetic pathways of cool-water shelf carbonate facies. Unpublished PhD thesis, lodged in the Library, University of Waikato, Hamilton, New Zealand.

Caron, V.; Nelson, C. S. 2003: Developing concepts of highresolution diagenetic stratigraphy for cool-water limestones: application to Pliocene Te Aute limestones, New Zealand, and their sequence stratigraphy. Carbonates and Evaporites 18: 63-85.

Caron, V.; Nelson, C. S.; Kamp, P. J. J. 2004: Transgressive surfaces of erosion as sequence boundary markers in cool-water shelf carbonates. Sedimentary Geology 164: 179-189.

Caron, V.; Nelson, C. S.; Kamp, P. J. J. in press: Sequence stratigraphic context of syndepositional diagenesis in coolwater shelf carbonates: Pliocene limestones, New Zealand. Journal of Sedimentary Research.

Cashman, S. M.; Kelsey; H. M.; Erdman, C. F.; Cutten, H. N. C.; Berryman, K. R. 1992: Strain partitioning between structural domains in the forearc of the Hikurangi subduction zone, New Zealand. Tectonics 11: 242-257.

Chayes, F. 1956: Petrographic modal analysis. New York, Waley. $113 \mathrm{p}$.

Croft Exploration Ltd 1992: Petroleum prospecting licence PPL38320, onshore New Zealand. Ministry of Economic Development, New Zealand, unpublished open-file petroleum report PR1837.

Dorsey, R. J.; Kidwell, S. M. 1999: Mixed carbonate-siliciclastic sedimentation on a tectonically active margin: example from the Pliocene of Baja California Sur, Mexico. Geology 27: 935-938.

Dunham, R. J. 1962: Classification of carbonate rocks according to depositional texture. In: Ham, W. E. ed. Classification of carbonate rocks. American Association of Petroleum Geologists Memoir 1: 108-121. 
Embry, A. F. 1995: Sequence boundaries and sequence hierarchies: problems and proposals. In: Steel, V. L.; Johannesen, E. P.; Mathieu, C. ed. Sequence stratigraphy: advances and applications for exploration and production in northwest Europe. Pp. 1-11.

Emery, D.; Myers, K. 1996: Sequence stratigraphy. Oxford, Blackwell Science. 297 p.

Erdman, C. F.; Kelsey, H. M. 1992: Pliocene and Pleistocene stratigraphy and tectonics, Ohara depression and Wakarara range, North Island, New Zealand. New Zealand Journal of Geology and Geophysics 35: 177-192.

Eyles, N.; Lagoe, M. B. 1989: Sedimentology of shell-rich deposits (coquinas) in the glaciomarine upper Cenozoic Yakataga Formation, Middleton Island, Alaska. Geological Society of America Bulletin 101: 129-142.

Field, B. D.; Uruski, C. I. and others 1997: Cretaceous-Cenozoic geology and petroleum systems of the east coast region, New Zealand. Institute of Geological \& Nuclear Sciences Memoir 19. Lower Hutt, New Zealand, Institute of Geological \& Nuclear Sciences Ltd. 301 p.

Galehouse, J. S. 1971: Point-counting. In: Carver, R. E. ed. Procedures in sedimentary petrology. New York, WileyInterscience. Pp. 385-407.

Gillespie, J. L.; Nelson, C. S. 1997: Mixed siliciclastic-skeletal carbonate facies on Wanganui shelf, New Zealand: a contribution to the temperate carbonate model. In: James, N. P.; Clarke, J. A. D. ed. Cool-water carbonates. Society for Sedimentary Geology Special Publication 56: 127-140.

Graafhuis, R. 2001: Stratigraphy and sedimentology of Pliocene strata in the forearc basin (Waikoau and Waikari River catchments), northern Hawke's Bay. Unpublished MSc thesis, lodged in the Library, University of Waikato, Hamilton, New Zealand.

Harmsen, F. J. 1985: Stratigraphy, depositional history and diagenesis of the Te Aute Group, a Pliocene temperate carbonatebearing sequence in southern Hawke's Bay, New Zealand. Unpublished $\mathrm{PhD}$ thesis, Victoria University of Wellington, Wellington, New Zealand. 208 p.

Harmsen, F. J. 1990: Te Aute Group limestones: a potential reservoir rock in the East Coast Basin, New Zealand. 1989 New Zealand Oil Exploration Conference Proceedings. Petroleum and Geothermal Unit, Energy and Resources Division, Ministry of Commerce, Wellington. Pp. 181-190.

Hayton, S.; Nelson, C. S.; Hood, S. D. 1995: A skeletal assemblage classification system for non-tropical carbonate deposits based on New Zealand Cenozoic limestones. Sedimentary Geology 100: 123-141.

Haywick, D. W. 1990: Stratigraphy, sedimentology, paleoecology and diagenesis of the Petane Group (Pliocene-Pleistocene) in the Tangoio, central Hawke's Bay, New Zealand. Unpublished PhD thesis, James Cook University of North Queensland, Australia.

Haywick, D. W. 2000: Recognition and distinction of normal and forced regression in cyclothemic strata: a Plio-Pleistocene case study from eastern North Island, New Zealand. In: Hunt, D.; Gawthorpe, R. L. ed. Sedimentary responses to forced regressions. Geological Society, London Special Publication 172: 193-215.

Haywick, D. W.; Carter, R. M.; Henderson, R. A. 1992: Sedimentology of 40000 year Milankovitch-controlled cyclothems from Central Hawke's Bay, New Zealand. Sedimentology 39: 675-696.

Henrich, R.; Freiwald, A. 1995: Controls on modern carbonate sedimentation on warm-temperate to arctic coasts, shelves and seamounts in the northern hemisphere: implications for fossil counterparts. Facies 32: 71-108.

Hunt, D.; Tucker, M. E. 1992: Stranded parasequences and the forced regressive wedge systems tract: deposition during base level fall. Sedimentary Geology 81: 1-9.
James, N. P. 1997: The cool-water carbonate depositional realm. In: James, N. P.; Clarke, J. A. D. ed. Cool-water carbonates. Society for Sedimentary Geology Special Publication 56: $1-20$.

James, N. P.; Boreen, T. D.; Bone, Y.; Feary, D. A. 1994: Holocene carbonate sedimentation on the west Eucla Shelf, Great Australian Bight: a shaved shelf. Sedimentary Geology 90: 161-177.

Kamp, P. J. J.; Nelson, C. S. 1987: Tectonic and sea-level controls on non-tropical limestones in New Zealand. Geology 15: 610-613.

Kamp, P. J. J.; Nelson, C. S. 1988: Nature and occurrence of modern and Neogene active margin limestones in New Zealand. New Zealand Journal of Geology and Geophysics 31: 1-20.

Kamp, P. J. J.; Harmsen, F. J.; Nelson, C. S.; Boyle, S. F. 1988: Barnacle-dominated limestone with giant cross-beds in a non-tropical, tide swept, Pliocene forearc seaway, Hawke's Bay, New Zealand. Sedimentary Geology 60: 173-195.

Lewis, K. B.; Pettinga, J. R. 1993: The emerging, imbricate frontal wedge of the Hikurangi margin. In: Ballance, P. F. ed. South Pacific sedimentary basins. Sedimentary basins of the world 2. Amsterdam, Elsevier. Pp. 225-250.

Light, J. M.; Wilson, J. B. 1998: Cool-water carbonate deposition on the West Shetland Shelf: a modern distally steepened ramp. In: Wright, V. P.; Burchette, T. P. ed. Carbonate ramps. Geological Society, London Special Publication 149: 73-105.

Lukasik, J. J.; James, N. P.; McGowran, B.; Bone, Y. 2000: An epeiric ramp: low-energy, cool-water carbonate facies in a Tertiary inland sea, Murray Basin, south Australia. Sedimentology 47: 851-881.

Naish, T.; Kamp, P. J. J. 1997: Sequence stratigraphy of sixth-order (41 k.y.) Pliocene-Pleistocene cyclothems, Wanganui basin, New Zealand: a case for the regressive systems tract. Geological Society of America Bulletin 109: 978-999.

Nelson, C. S. 1978: Temperate shelf carbonate sediments in the Cenozoic of New Zealand. Sedimentology 25: 737-771.

Nelson, C. S.; Harris, G. J.; Young, H. R. 1988a: Burial-dominated cementation in non-tropical carbonates of the Oligocene Te Kuiti Group, New Zealand. Sedimentary Geology 60: 233-250.

Nelson, C. S.; Keane, S. L.; Head, P. S. 1988b: Non-tropical carbonate deposits on the modern New Zealand shelf. Sedimentary Geology 60: 71-94.

Nelson, C. S.; Winefield, P. R.; Hood, S. D.; Caron, V.; Pallentin, A.; Kamp, P. J. J. 2003: Pliocene Te Aute limestones, New Zealand: expanding concepts for cool-water shelf carbonates. New Zealand Journal of Geology and Geophysics 46: 407-424.

Nummedal, D.; Swift, D. J. P. 1987: Transgressive stratigraphy at sequence-bounding unconformities: some principles derived from Holocene and Cretaceous examples. In: Nummedal, D.; Pilkey, O. H. ed. Sea-level fluctuation and coastal evolution. SEPM Special Publication 41: 241-260.

Nummedal, D.; Riley, G. W.; Templet, P. L. 1993: High-resolution sequence architecture: a chronostratigraphic model based on equilibrium profile studies. In: Posamentier, H.; Summerhayes, C. P.; Haq, B. U.; Allen, C. P. ed. Sequence stratigraphy and facies associations. SEPM Special Publication 18: 55-68.

Pedley, M.; Grasso, M. 2002: Lithofacies modelling and sequence stratigraphy in microtidal cool-water carbonates: a case study from the Pleistocene of Sicily, Italy. Sedimentology 49: 533-553.

Pomar, L. 2001: Types of carbonate platforms: a genetic approach. Basin Research 13: 313-334. 
Probert, P. K.; Batham, E. J.; Wilson, J. B. 1979: Epibenthic macrofauna off southeastern New Zealand and mid-shelf bryozoan dominance. New Zealand Journal of Marine and Freshwater Research 13: 379-392.

Ricketts, B. D.; Caron, V.; Nelson, C. S. 2004: A fluid flow perspective on the diagenesis of Te Aute limestones. New Zealand Journal of Geology and Geophysics 47: 823-838 (this issue).

Schlager, W. 1999: Type 3 sequence boundary. In: Harris, P. M.; Saller, A. H.; Simo J. A. ed. Advances in carbonate sequence stratigraphy: application to reservoirs, outcrops and models. SEPM Special Publication 63: 35-45.

Scoffin, T. P. 1988: The environments of production and deposition of calcareous sediments on the west shelf of Scotland. Sedimentary Geology 60: 107-124.

Tucker, M. E. 1993: Carbonate diagenesis and sequence stratigraphy. In: Wright, V. P. ed. Oxford, Blackwell Scientific. Sedimentology Review 1: 51-72.
Vail, P. R.; Audemard, F.; Bowman, S. A.; Eisner, P. N.; Perez-Cruz, C. 1991: The stratigraphic signatures of tectonics, eustasy and sedimentology - an overview. In: Einsele, G.; Ricken, W.; Seilacher, A. ed. Cycles and events in stratigraphy. Berlin, Heidelberg, Springer-Verlag. Pp. 617-659.

Van Wagoner, J. C.; Posamentier, H. W.; Mitchum, R. M. J.; Vail, P. R.; Sarg, J. F.; Loutit, T. S.; Hardenbol, J. 1988: An overview of the fundamentals of sequence stratigraphy and key definitions. In: Wilgus, C. K.; Hastings, B. S.; Kendall, C. G. S. C.; Posamentier, H. W.; Ross, C. A.; Van Wagoner, J. C. ed. Sea-level changes: an integrated approach. SEPM Special Publication 42: 39-45.

Vitale, F. P. 1998: Stacking pattern and tectonics: field evidence from Pliocene growth folds of Sicily (central Mediterranean). In: Mesozoic and Cenozoic sequence stratigraphy of European basins. SEPM Special Publication 60: 179-197.

Walker, R. G. 1995: Sedimentary and tectonic origin of a transgressive surface of erosion: Viking Formation, Alberta, Canada. Journal of Sedimentary Research B65: 209-221.

Wright, V. P.; Burchette, T. P. 1996: Shallow-water carbonate environments. In: Reading, H. G. ed. Sedimentary environments: processes, facies and stratigraphy. Oxford, Blackwell Science Ltd. Pp. 325-394. 